This document was prepared in conjunction with work accomplished under Contract No. DE-AC09-96SR18500 with the U. S. Department of Energy.

\title{
DISCLAIMER
}

This report was prepared as an account of work sponsored by an agency of the United States Government. Neither the United States Government nor any agency thereof, nor any of their employees, makes any warranty, express or implied, or assumes any legal liability or responsibility for the accuracy, completeness, or usefulness of any information, apparatus, product or process disclosed, or represents that its use would not infringe privately owned rights. Reference herein to any specific commercial product, process or service by trade name, trademark, manufacturer, or otherwise does not necessarily constitute or imply its endorsement, recommendation, or favoring by the United States Government or any agency thereof. The views and opinions of authors expressed herein do not necessarily state or reflect those of the United States Government or any agency thereof.

This report has been reproduced directly from the best available copy.

Available for sale to the public, in paper, from: U.S. Department of Commerce, National Technical Information Service, 5285 Port Royal Road, Springfield, VA 22161, phone: (800) 553-6847, fax: (703) 605-6900

email: orders@ntis.fedworld.gov

online ordering: http://www.ntis.gov/help/index.asp

Available electronically at http://www.osti.gov/bridge

Available for a processing fee to U.S. Department of Energy and its contractors, in paper, from: U.S. Department of Energy, Office of Scientific and Technical Information, P.O. Box 62, Oak Ridge, TN 37831-0062,

phone: (865)576-8401,

fax: (865)576-5728

email: $\underline{\text { reports@ adonis.osti.gov }}$ 


\section{Testing of the In Situ, Mixed Iron Oxide (IS-MIO) Alpha Removal Process}

Michael R. Poirier, David T. Herman, Paul R. Burket, Thomas B. Peters, Steven M. Serkiz and Samuel D. Fink

June 29, 2004 


\section{SUMMARY}

One of the throughput limitations for the Actinide Removal Process (ARP) and Salt Waste Processing Facility (SWPF) is the lengthy sorption time of plutonium on monosodium titanate (MST). Argonne National Laboratory (ANL) personnel proposed use of the In-Situ-Mixed Iron Oxide (IS-MIO) process, which removes strontium and actinides from waste streams with faster reaction kinetics than the MST process. The Savannah River National Laboratory (SRNL) and ANL received funding from the Department of Energy - Head Quarters (DOE-HQ), Office of Cleanup Technologies (EM-21), via the National Energy Technology Laboratory (NETL), to develop the IS-MIO process for deployment at the Savannah River Site (SRS).

Personnel performed simulant filtration tests to evaluate the process. They prepared $100 \mathrm{~L}$ of simulated SRS high level waste, added IS-MIO solutions to the simulated waste, mixed the solutions for four hours, and filtered the slurry in a bench-scale crossflow filter. The simulant was designed to maximize strontium solubility; it was not designed to match a particular tank composition. The crossflow filter was 3/8" internal diameter, 2 feet long, and possessing a 0.196 $\mathrm{ft}^{2}$ internal surface area.

Researchers also performed a series of decontamination tests using actual waste. They prepared a multi-tank composite (from Tanks $11 \mathrm{H}, 30 \mathrm{H}, 32 \mathrm{H}$, and $39 \mathrm{H}$ ), adjusted it to $\sim 5.6 \mathrm{M}$ sodium, and allowed it to equilibrate. They used this material in six tests. Four of the tests utilized IS-MIO solutions, one of the tests used MST, and one test served as a control. In each test, personnel sampled the supernate at regular intervals and analyzed for strontium and actinides to determine the effective removal capability.

The conclusions from this work follow.

- The IS-MIO solids do not produce an increase in filter flux. The increased flux observed in some comparisons is due to differences in operating conditions rather than to improved filterability of the IS-MIO solids.

- Filter flux with sludge and IS-MIO solids increases with increasing axial velocity. A similar correlation occurred with sludge and MST solids.

- The IS-MIO particles are initially larger than MST particles. Because of shear, by the end of the test, the IS-MIO solids were approximately the same size as MST solids.

- An initial plutonium Decontamination Factor (DF) of $\sim 7$ resulted. This declined to a DF of $\sim 1.6$ over a period of two weeks.

- An initial strontium DF of $\sim 110$ occurred. This increased to a DF of $\sim 128$ after a period of two weeks. In comparison, MST provided a DF of $\sim 67$.

- The IS-MIO process provided no significant removal of uranium from solution. 


\section{INTRODUCTION}

Nearly 36 million gallons of radioactive waste are currently stored in tanks at the Savannah River Site in South Carolina. This waste contains hazardous radioactive isotopes, including cesium $(\mathrm{Cs})$, strontium $(\mathrm{Sr})$, neptunium $(\mathrm{Np})$, plutonium $(\mathrm{Pu})$, and americium $(\mathrm{Am})$. Because of the high cost associated with disposal of the High Level Waste (HLW), it is desirable to minimize its volume. The current SRS baseline technology is to remove $\mathrm{Sr}$ and actinides (i.e., $\mathrm{Pu}, \mathrm{Am}, \mathrm{Np}$ ) from the alkaline supernatant with MST and to remove cesium with caustic side solvent extraction. ${ }^{1,2,3}$ The concentrated waste stream is to be vitrified. Unfortunately, the MST process requires a long sorption time ( 24 hours), and titanium solubility in glass is currently limited to $2 \mathrm{wt} \%$ by available test data.

SRS has been testing several materials as alternatives to MST. ${ }^{4,5}$ The IS-MIO (in situ-formed mixed iron oxides) process, is proposed by ANL as an alternative to MST for the removal of $\mathrm{Sr}$ and actinides. Figure 1 shows a schematic of the process. The process adds a solution containing $\mathrm{Fe}$ (II) and $\mathrm{Fe}$ (III) ions to alkaline waste, which forms a redox (Fe(II) and $\mathrm{Fe}$ (III)) mixture of iron oxide and hydroxide precipitates. ${ }^{6,7}$ The decontamination from the IS-MIO process is effectively complete within several hours, much faster than the MST process. The ISMIO particles adsorb or occlude the $\mathrm{Sr}$ and actinides from the solution during the precipitation process. Furthermore, the iron is already present in the waste as it is a major component of the sludge residing in the tanks, and it is more soluble in glass than titanium.

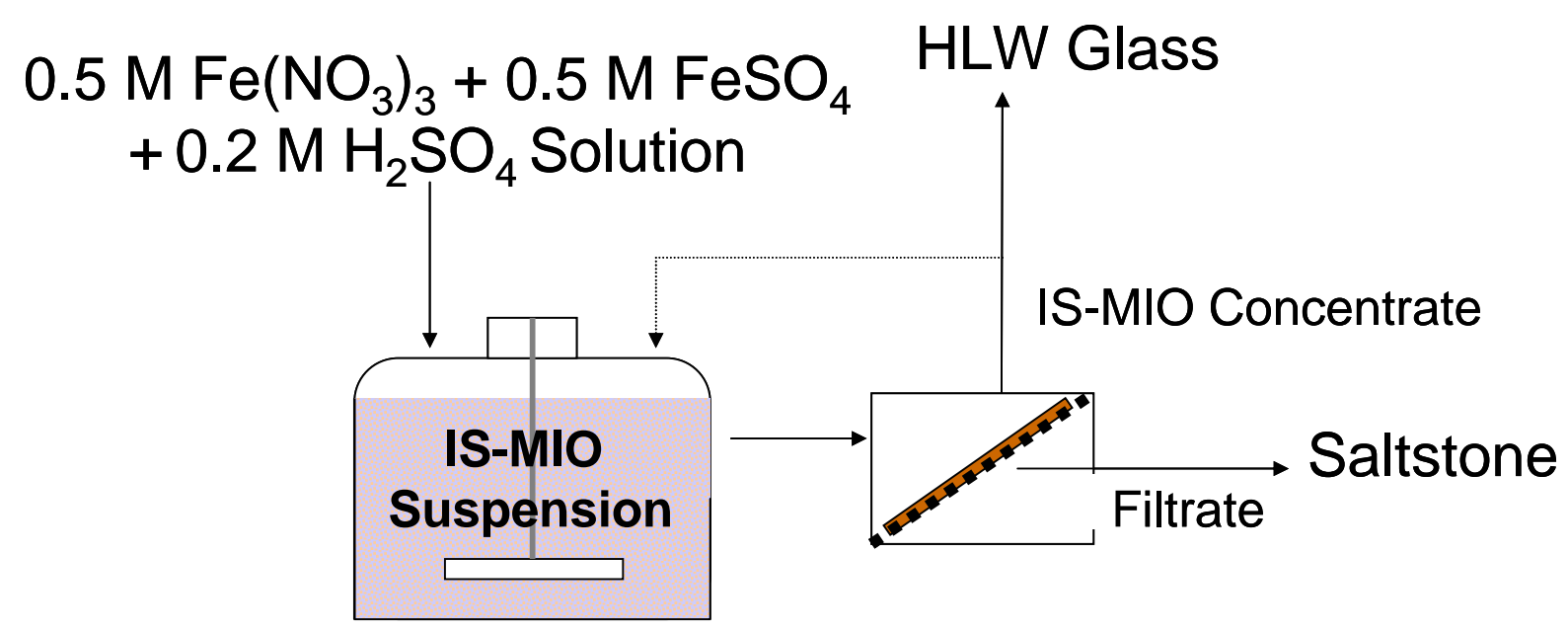

Figure 1. In Situ-Mixed Iron Oxide Process

ANL personnel performed tests to evaluate the process with SRS simulated waste and to refine the operating parameters. ${ }^{8,9}$ Following those tests, SRNL personnel conducted simulant filtration tests and actual waste decontamination tests. This report describes the simulant filtration tests and actual waste decontamination tests. 


\section{TESTING}

\section{Filter Testing}

Personnel prepared 100 L of simulated SRS HLW Salt Solution with the composition indicated in Table 1.

\section{Table 1. Simulated SRS High Level Waste Salt Solution ${ }^{10}$}

$\begin{array}{cc}\text { Species } & \text { Concentration } \\ & 1.33 \mathrm{M} \\ \mathrm{NaNO}_{3} & 2.60 \mathrm{M} \\ \mathrm{NaAl}_{3}(\mathrm{OH})_{4} & 0.43 \mathrm{M} \\ \mathrm{NaNO}_{2} & 0.13 \mathrm{M} \\ \mathrm{Na}_{2} \mathrm{SO}_{4} & 0.52 \mathrm{M} \\ \mathrm{Na}_{2} \mathrm{CO}_{3} & 0.026 \mathrm{M} \\ \text { Simulated Sludge Batch } 2 & 0.6 \mathrm{~g} / \mathrm{L}\end{array}$

The researchers prepared an iron (II) solution containing $1 \mathrm{M}$ iron (II) sulfate and $0.4 \mathrm{M}$ sulfuric acid, and an iron (III) solution containing $1 \mathrm{M}$ iron (III) nitrate. They mixed the iron (II) and iron (III) solutions together and immediately added $360 \mathrm{~mL}$ of the combined solution to the $100 \mathrm{~L}$ of simulated SRS HLW (at a rate of $40 \mathrm{~mL} / \mathrm{min}$ ) to create a feed slurry containing $0.2 \mathrm{~g} / \mathrm{L}$ iron. The addition rate approximately matches the addition rate in the beaker tests conducted at ANL.

The personnel mixed the feed slurry for four hours and collected feed slurry samples prior to the addition of the iron solution, 30 minutes after the iron solution addition, 1 hour after addition, 2 hours after addition, 3 hours after addition, and 4 hours after addition. A four blade radial flow type impeller @97 rpm was used. The researchers immediately filtered the feed samples with a 0.2 micron syringe filter, and submitted them to the Analytical Development Section (ADS) for strontium and sulfate analysis. Personnel also measured particle growth with a Focused Beam Reflectance Measurement probe (Lasentec $®)$.

After four hours of mixing, the filtration started. Figure 2 shows the tank used for the IS-MIO reaction and the filtration unit. Personnel performed filtration tests at the conditions shown in Table 2. They recycled filtrate and concentrate to the feed tank. Prior to the start of each test in Table 2, they backpulsed the filter. Each test lasted for one hour with data collected every 15 minutes. Feed pressure, concentrate pressure, filtrate pressure, feed flowrate, filtrate flowrate and temperature data were collected. 
Rev. 0

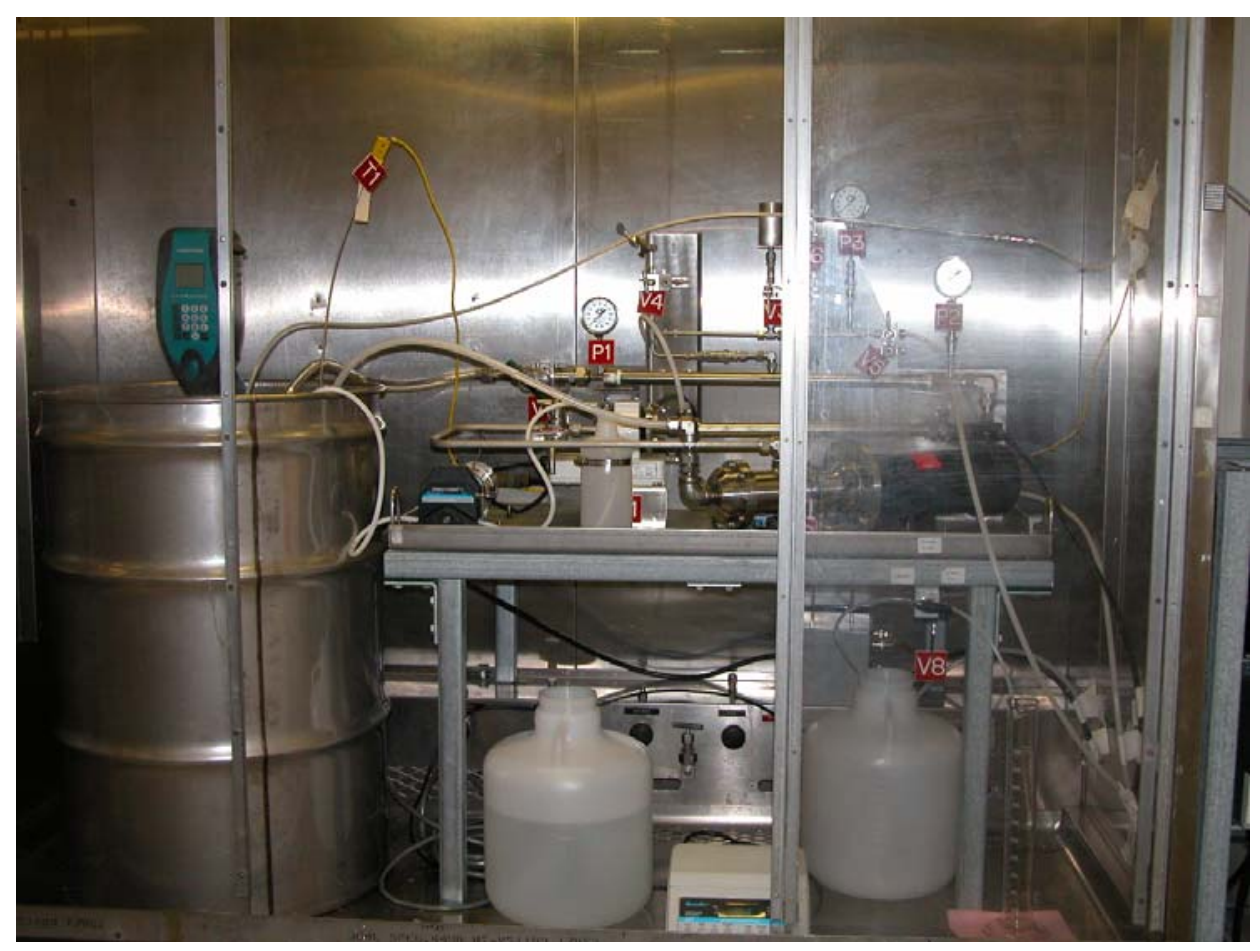

Figure 2. Crossflow Filter Unit

\section{Table 2. Filtration Matrix Conditions}

$\begin{array}{cc}\text { Axial Velocity (ft/s) } & \text { Transmembrane Pressure (psi) } \\ 9 & 30 \\ 12 & 40 \\ 4 & 30 \\ 9 & 15 \\ 12 & 20 \\ 9 & 30 \\ 6 & 40 \\ 9 & 45 \\ 14 & 30 \\ 6 & 20 \\ 9 & 30\end{array}$

After completing the tests described by Table 2, personnel continued the filtration test by removing the filtrate. Concentration occurred at $9 \mathrm{ft} / \mathrm{s}$ axial velocity and $40 \mathrm{psi}$ transmembrane pressure. Personnel recorded the operating conditions and filter flux while the feed slurry was reduced from $100 \mathrm{~L}$ to approximately $2 \mathrm{~L}$.

Researchers then performed matrix tests with the concentrated slurry at the conditions shown in Table 2. Researchers recycled filtrate and concentrate to the feed tank. Prior to the start of each 
test, they backpulsed the filter. They conducted each test for one hour, collecting data every 15 minutes.

\section{Actual Waste Decontamination Tests}

Personnel prepared $2 \mathrm{~L}$ of a composite sample of Tank $11 \mathrm{H}, 30 \mathrm{H}, 32 \mathrm{H}$, and $39 \mathrm{H}$ supernates. They allowed the composite to equilibrate for 48 days and used this mixture in all of the tests detailed below. Each test occurred in a $250 \mathrm{~mL}$ poly bottle, and unless otherwise noted, used $120 \mathrm{~mL}$ of composite solution. A controlled temperature water bath/magnetic stirrer combination (Figure 3) provided temperature control and adequate mixing.

Two tests serve as duplicate reactions and used the IS-MIO process as follows. One day before the tests, personnel prepared a mixed iron solution consisting of $1 \mathrm{M} \mathrm{Fe}$ (III) nitrate $\left(\mathrm{Fe}\left(\mathrm{NO}_{3}\right)_{3} \cdot 9 \mathrm{H}_{2} \mathrm{O}\right)$ and $1 \mathrm{M} \mathrm{Fe}(\mathrm{II})$ sulfate $\left(\mathrm{FeSO}_{4} \cdot 7 \mathrm{H}_{2} \mathrm{O}\right)$ in $0.4 \mathrm{M} \mathrm{H}_{2} \mathrm{SO}_{4}$. Technicians mixed $0.36 \mathrm{~mL}$ of this iron solution with $0.64 \mathrm{~mL}$ of distilled deionized (DDI) water to generate $1 \mathrm{~mL}$ of solution. The water dilution allowed for easy pipetting operations. While stirring the waste composite, technicians injected this $1 \mathrm{~mL}$ of solution below the surface in one aliquot. The goal of the iron addition was $0.2 \mathrm{~g} / \mathrm{L}$ of iron in the slurry. Researchers sampled the slurry at 0 (just before iron addition), 1/2, 1, 2, 4, 12, 24, 168, and 336 hours (although not all samples were sent forward to ADS for analysis). They filtered the samples through $0.1 \mu \mathrm{m}$ polyvinylidene

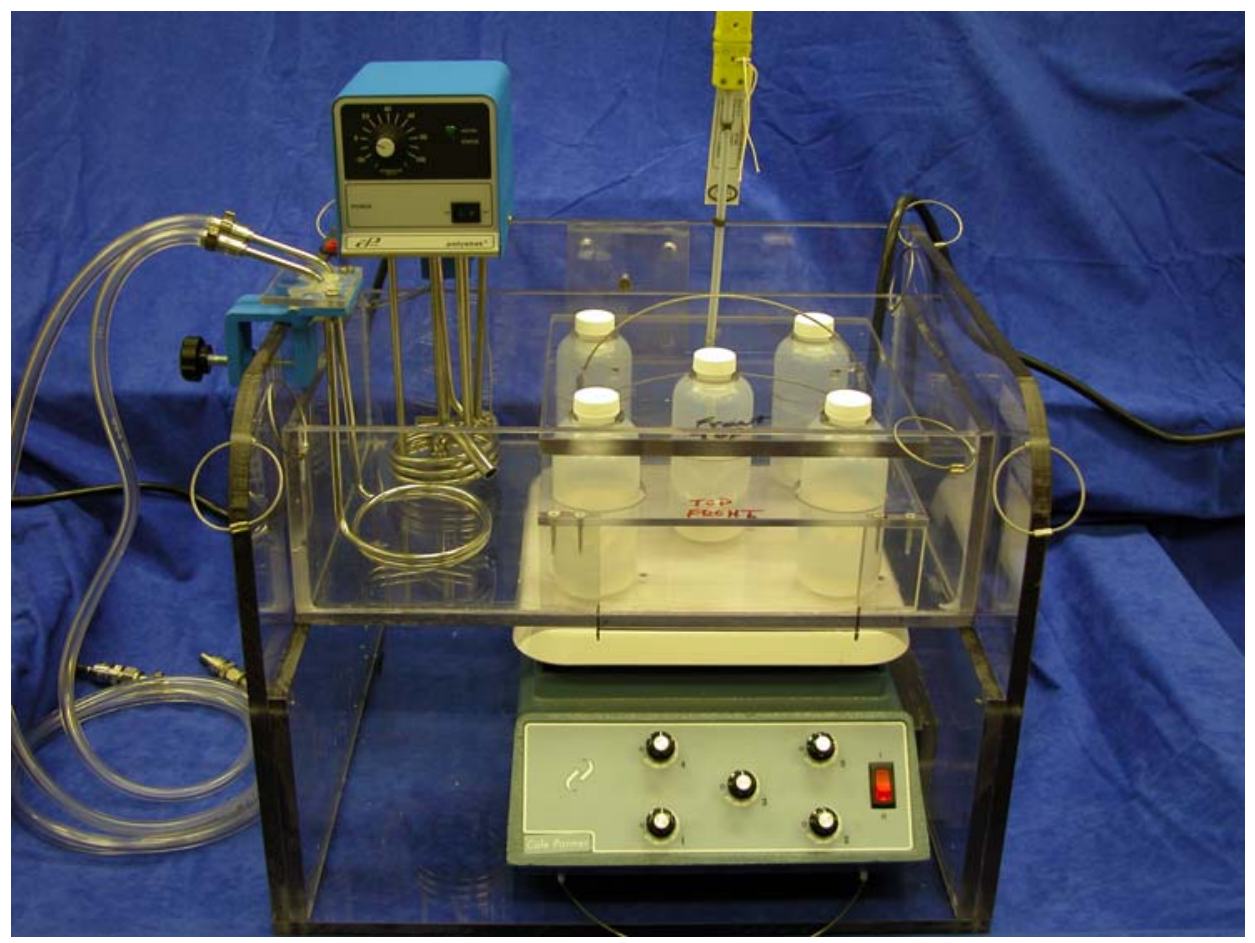

Figure 3. Actual Waste Test Equipment 
difluoride (PVDF) syringe filter disks, diluted and acidified with 2.0 M nitric acid for at least 2 hours, and analyzed for $\mathrm{Pu}$ and $\mathrm{Sr}$ by radiocounting and for $\mathrm{Np}$ and $\mathrm{U}$ by Inductively Coupled Plasma - Mass Spectroscopy (ICP-MS).

The third test used MST as the sorbent with the following procedure. While stirring the solution, personnel added $0.4 \mathrm{~g} / \mathrm{L}$ of MST (from batch QAB417) above the surface to one of the bottles. Researchers then sampled the composite solution at 0 (just before MST addition), 2, 6, 12, and 24 hours. Technicians filtered the samples through $0.1 \mu \mathrm{m}$ PVDF syringe filter disks, diluted and acidified with $2.0 \mathrm{M}$ nitric acid for at least 2 hours, and analyzed for $\mathrm{Pu}$ and $\mathrm{Sr}$ by radiocounting and for $\mathrm{Np}$ and $\mathrm{U}$ by ICPMS.

A fourth test omitted any sorbent from the $120 \mathrm{~mL}$ composite sample. This bottle served as the control. Personnel sampled the solution after $0,1 / 2,1,2,4,12,24$, and 168 hours. They filtered the samples through $0.1 \mu \mathrm{m}$ PVDF syringe filter disks, diluted and acidified with $2.0 \mathrm{M}$ nitric acid for at least 2 hours, and analyzed for $\mathrm{Pu}$ and $\mathrm{Sr}$ by radiocounting and for $\mathrm{Np}$ and $\mathrm{U}$ by ICPMS.

After the four initial tests completed, one of the researchers discovered a calculational error that resulted in only $0.17 \mathrm{~g} / \mathrm{L}$ iron added to the first two tests rather than the desired $0.2 \mathrm{~g} / \mathrm{L}$. To recover from this error, the authors decided to conduct two additional tests. Using the material from the control, personnel completed two more tests using $60 \mathrm{~mL}$ each of the composite. After consultation with colleagues from ANL, the authors decided to use $0.25 \mathrm{~g} / \mathrm{L}$ of iron (to bracket the original desired iron concentration target of $0.2 \mathrm{~g} / \mathrm{L}$ ).

These final two tests are duplicate reactions using the IS-MIO process as follows. One day before the tests, personnel prepared a mixed iron solution consisting of $1 \mathrm{M} \mathrm{Fe}$ (III) nitrate $\left(\mathrm{Fe}\left(\mathrm{NO}_{3}\right)_{3} \cdot 9 \mathrm{H}_{2} \mathrm{O}\right)$ and $1 \mathrm{M} \mathrm{Fe}(\mathrm{II})$ sulfate $\left(\mathrm{FeSO}_{4} \cdot 7 \mathrm{H}_{2} \mathrm{O}\right)$ in $0.4 \mathrm{M} \mathrm{H}_{2} \mathrm{SO}_{4}$. Technicians mixed $0.228 \mathrm{~mL}$ of this iron solution with $0.772 \mathrm{~mL}$ of DDI water to generate $1 \mathrm{~mL}$ of solution. The water dilution allowed easy pipetting operations. While stirring the actual waste composite, personnel injected this $1 \mathrm{~mL}$ of solution below the surface ( 1-2"). The amount of iron solution added resulted in a slurry contained $0.25 \mathrm{~g} / \mathrm{L}$ of added iron. Researchers sampled the slurry at 0 (just before iron addition), 1/2, 1, 2, 4, 12, and 24 hours. They filtered samples through $0.1 \mu \mathrm{m}$ PVDF syringe filter disks, diluted and acidified with 2.0 M nitric acid for at least 2 hours, and analyzed for Pu and Sr by radiocounting and for Np and U by ICPMS.

\section{RESULTS}

\section{Filter Testing at Low Solids Content}

Figures 4 and 5 show the filter flux with the initial slurry plotted as a function of transmembrane pressure and axial velocity. The plots also show comparable bench-scale data collected at the Idaho National Engineering and Environmental Laboratory (INEEL). ${ }^{11}$ The INEEL tests used a 
filter unit of the same design as the one in the current test and used the same operating parameters.

Filter flux appears to correlate with axial velocity, but not with transmembrane pressure (TMP). The authors performed statistical analyses with $\mathrm{JMP}^{\circledR}$ software (see Appendix A), and determined that the correlation between filter flux and axial velocity is statistically significant, but found no statistically significant correlation between filter flux and transmembrane pressure.

Filter flux in the present test appears to be greater than the filter flux in the tests performed at INEEL. Statistical analyses (see Appendix A) show the flux during the IS-MIO test is greater ( $30 \%$ ) than the flux during the INEEL test using MST. This effect could be due to differences in the solid particle characteristics in the two feed streams or to differences in the solids loading (0.06 wt \% with IS-MIO feed versus $0.29 \mathrm{wt} \%$ with MST feed). A review of previous data from tests with sludge-only feed and sludge plus MST feed shows that increasing the solids loading from $0.06 \mathrm{wt} \%$ to $0.29 \mathrm{wt} \%$ leads to a $30 \%$ decrease in filter flux. ${ }^{12,13}$ Therefore, the difference in flux is most likely due to differences in solids loading.

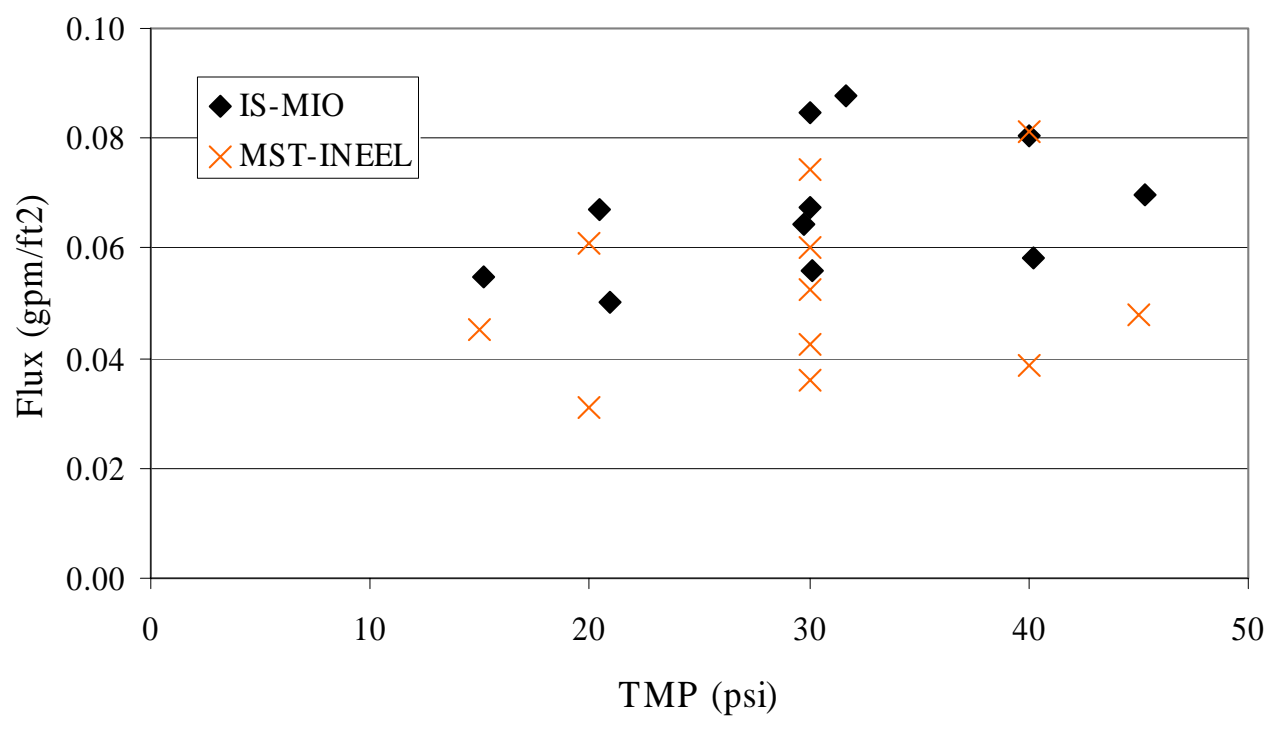

Figure 4. Filter flux as a Function of Transmembrane Pressure with Initial Feed Slurry 


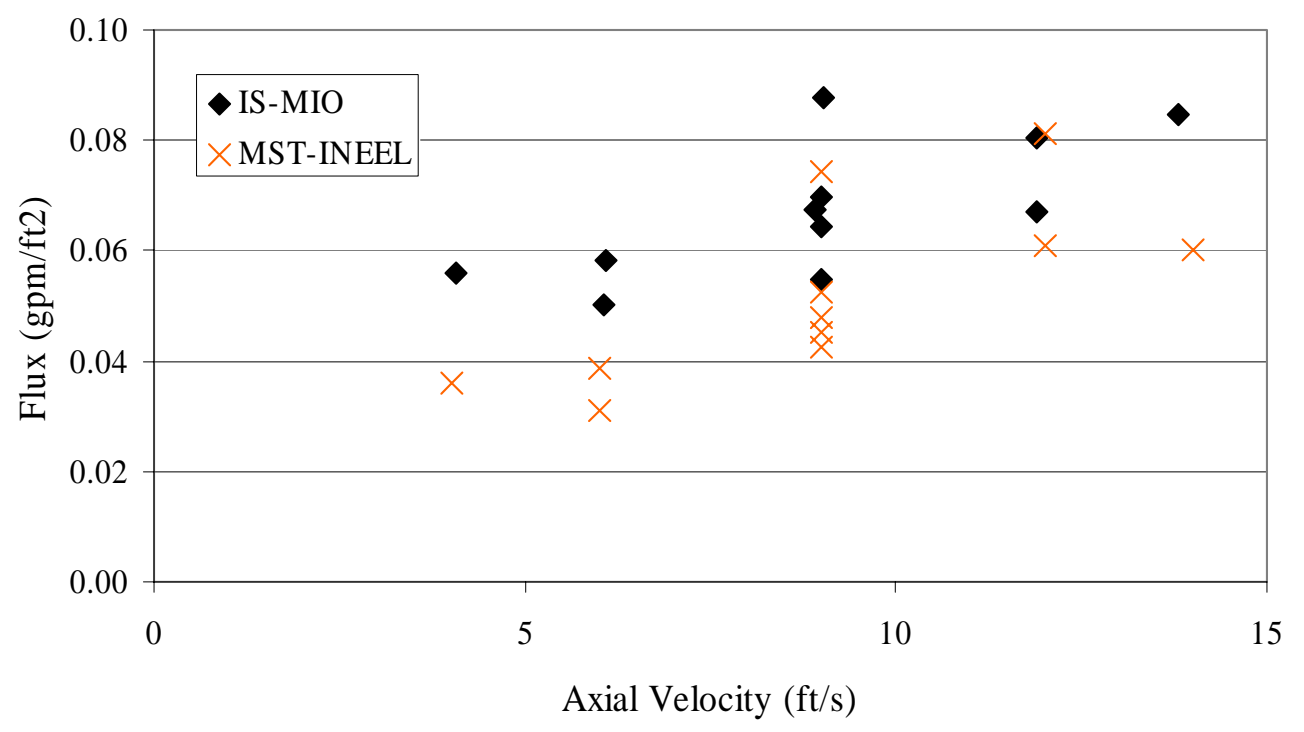

Figure 5. Filter flux as a Function of Axial Velocity with Initial Feed Slurry

\section{Filter Testing during Concentration}

Figure 6 shows the flux during the concentration of the IS-MIO solids from 0.06 wt $\%$ to 3 wt $\%$. The plot also shows data collected during the concentration of sludge and MST slurry from 0.09 wt \% to 5.0 wt \% with the Parallel Rheology Experimental Filter (PREF). ${ }^{14}$ Statistical analyses of the data show the average flux during the IS-MIO test is $10 \%$ higher than the average flux during the MST test and the difference is statistically significant.

Plausible reasons for the differences in flux are the following: differences in properties of the IS-MIO and MST solids (see particle size discussion later), differences in filter operating parameters, differences in final solids loading during concentration, or differences in test operational time.

The Cells Unit Filter (CUF) has a smaller tube diameter than the Parallel Rheology Experimental Filter (i.e., 3/8 inch versus $1 / 2$ inch). The smaller diameter leads to higher wall shear stress for the same axial velocity. Many filtration models show filter flux increasing with wall shear stress. The CUF has a shorter tube length than the PREF (i.e., $2 \mathrm{ft}$ versus $4 \mathrm{ft}$ ). With a shorter tube length, a larger fraction of the tube is in the entrance region. The entrance region of the tube has a higher mass transfer coefficient, and therefore a higher filter flux, than the remainder of the tube. During the concentration step, the CUF operated at $9 \mathrm{ft} / \mathrm{s}$ and $40 \mathrm{psi}$. The PREF operated at $6 \mathrm{ft} / \mathrm{s}$ and $15-30 \mathrm{psi}$. Higher axial velocity and TMP lead to higher filter flux. The final solids loading in the present test reached 3 wt \% versus 5 wt \% in the PREF test. Lower solids loadings lead to higher filter flux. The PREF continued for 73 hours versus 48 hours in the current test. The longer duration could allow more particle shearing and more filter fouling. In addition, the PREF test used a 0.5 micron filter. Theory and the INEEL data indicate filter cake resistance should dominate filter media resistance and there should be no significant difference 
in flux between the 0.1 and 0.5 micron filters. ${ }^{11,15}$ However, some SRNL test data shows a 0.1 micron filter produces higher flux than a 0.5 micron filter. ${ }^{16,17}$

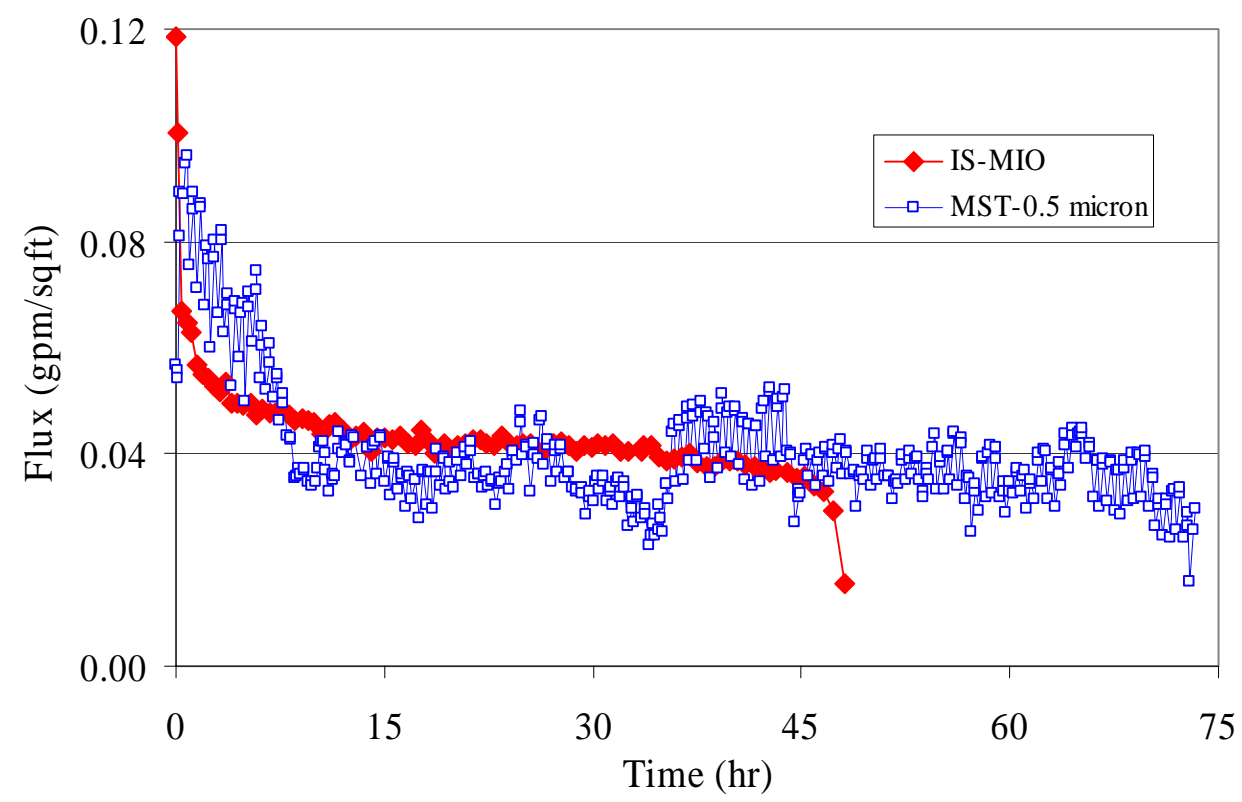

Figure 6. Filter Flux during Solids Concentration

\section{Filter Testing after Concentration}

Figures 7 and 8 show the filter flux with the concentrated slurry plotted as a function of transmembrane pressure and axial velocity. The plots also show and bench-scale data collected at INEEL using a sludge and MST slurry for comparison.

Filter flux appears to correlate with axial velocity, but not with transmembrane pressure. The authors performed statistical analyses (see Appendix A), and determined that the correlation between filter flux and axial velocity is statistically significant, but found no statistically significant correlation between filter flux and transmembrane pressure.

Filter flux in the present test appears to be less than the filter flux in the tests performed at INEEL using a sludge and MST slurry. Statistical analyses (Appendix A) show the flux during the IS-MIO test was $\sim 75 \%$ less than the flux during the MST test. In addition, the solids loading in the IS-MIO test was $3 \mathrm{wt} \%$ versus $4.5 \mathrm{wt} \%$ in the MST test. 


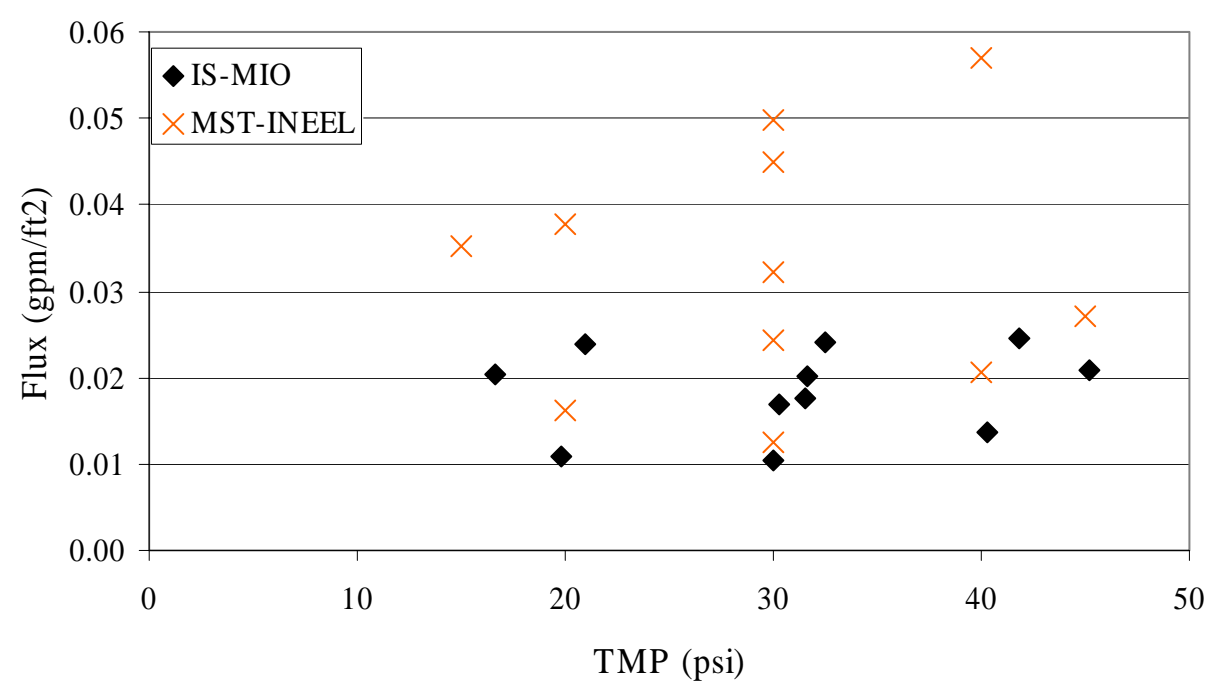

Figure 7. Filter flux with Concentrated IS-MIO Slurry

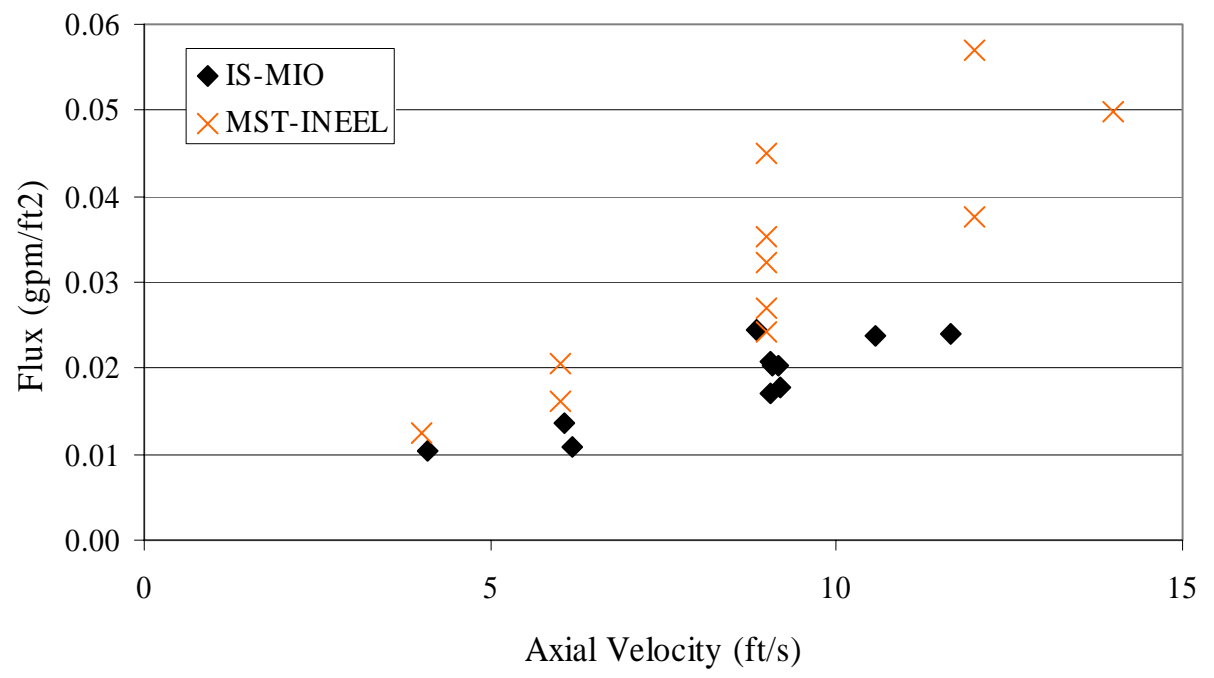

Figure 8. Filter flux with Concentrated IS-MIO Slurry

\section{Particle Size Data}

Personnel collected particle measurements with a Focused Beam Reflectance Measurement (FBRM) probe (Lasentec $®$ ). The probe works in the following manner. Personnel installed the probe in the feed tank. The laser beam projects through the window of the FBRM probe and focuses just outside the window surface. This focused beam follows a path around the circumference of the probe window. As particles pass by the window surface, the focused beam will intersect the edge of a particle. The particle will backscatter laser light. The particle will continue to backscatter the light until the focused beam reaches the opposite edge of the particle. The instrument collects the backscattered light and converts it into an electronic signal. 
The FBRM isolates the time of backscatter from one edge of an individual particle to its opposite edge. The software records the product of the time multiplied by the scan speed as a chord length. A chord length is a straight line between any two points on the edge of a particle or particle structure (agglomerate). FBRM typically measures tens of thousands of chords per second, resulting in a robust number-by-chord-length distribution.

The chord-length distribution provides a means of tracking changes in both particle dimension and particle population. The calculations do not assume a particle shape. The chord-length distribution is essentially unique for any given particle size and shape distribution. Assuming the average particle shape remains constant over millions of particles, changes to the chord-length distribution reflect solely a function of the change in particle dimension and particle number.

Figure 9 shows the number of particles counted prior to and during the four hours following the IS-MIO solution addition. Overall, the total number of particles doubled during the four hour ISMIO reaction time. Most of the particles were in the 10-20 micron range, which is consistent with Lasentec ${ }^{\circledR}$ data collected during other filtration tests with sludge and MST solids. The number of particles approximately doubled in the $1-5$ micron, $5-10$ micron, and $10-20$ micron ranges. The plot also shows that particles form over four hours.

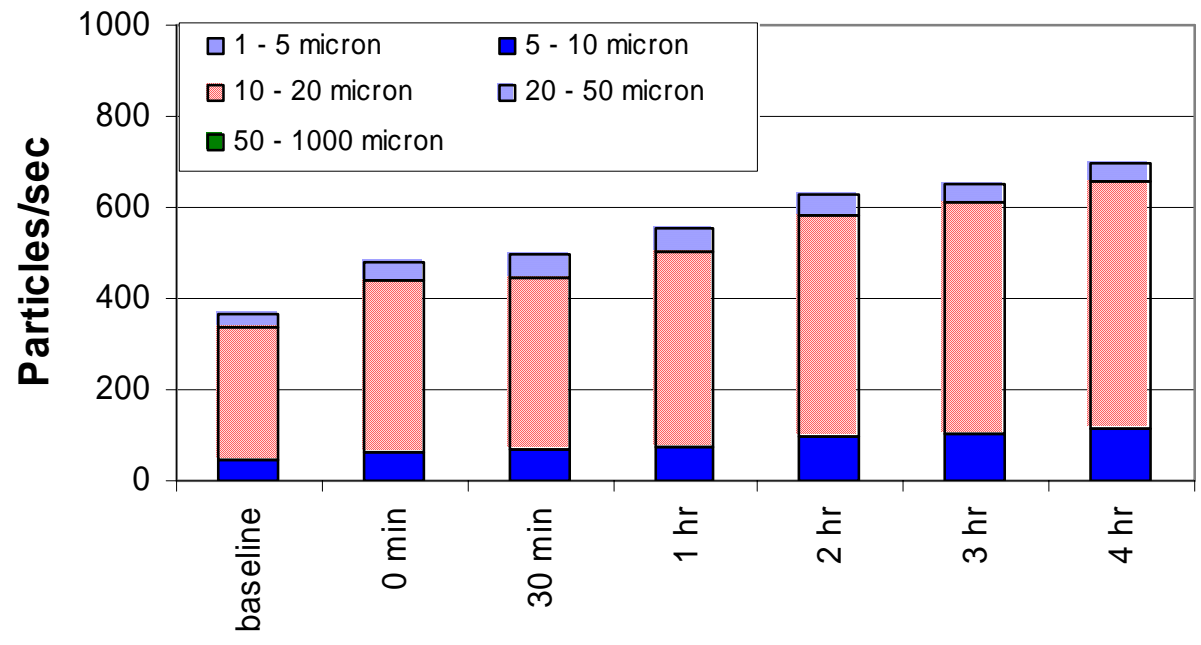

Figure 9. Change in Particles During IS-MIO Process

Figure 10 shows the particle size distribution of the solids during the IS-MIO reaction and the filtration step. The median particle size is approximately the same during the four hour reaction (39-43 micron), but it decreases from 28 micron to 6 micron during the concentration step of the filtration process. 


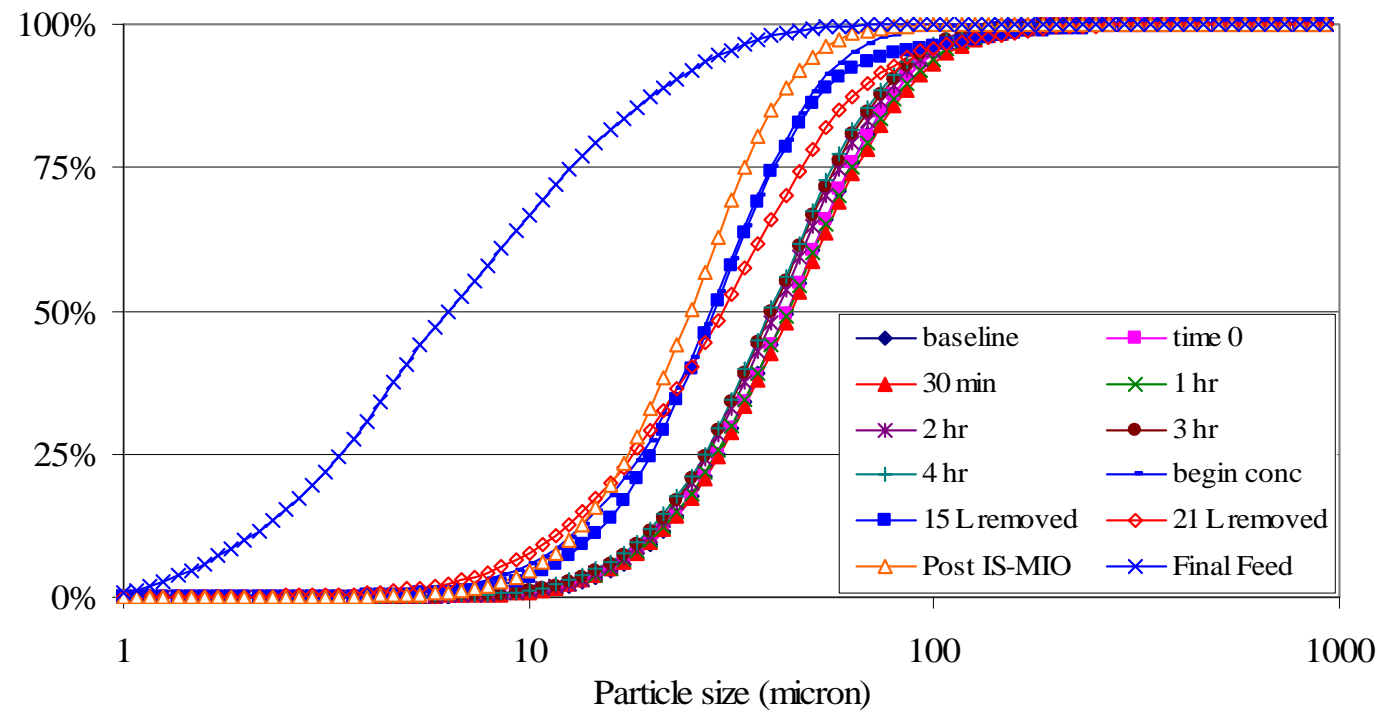

Figure 10. Particle Size Distribution during IS-MIO Process

Figure 11 compares the particle size during the filtration step with data collected during filtration tests at INEEL using a slurry of MST and sludge. The particle size in the present test is larger than the particle size in the INEEL tests. The median particle size at the start of the concentration step equals 28 micron versus 21 micron in the INEEL test. At the end of the filtration test, the median particle size equals 6 micron versus 5 micron in the INEEL test.

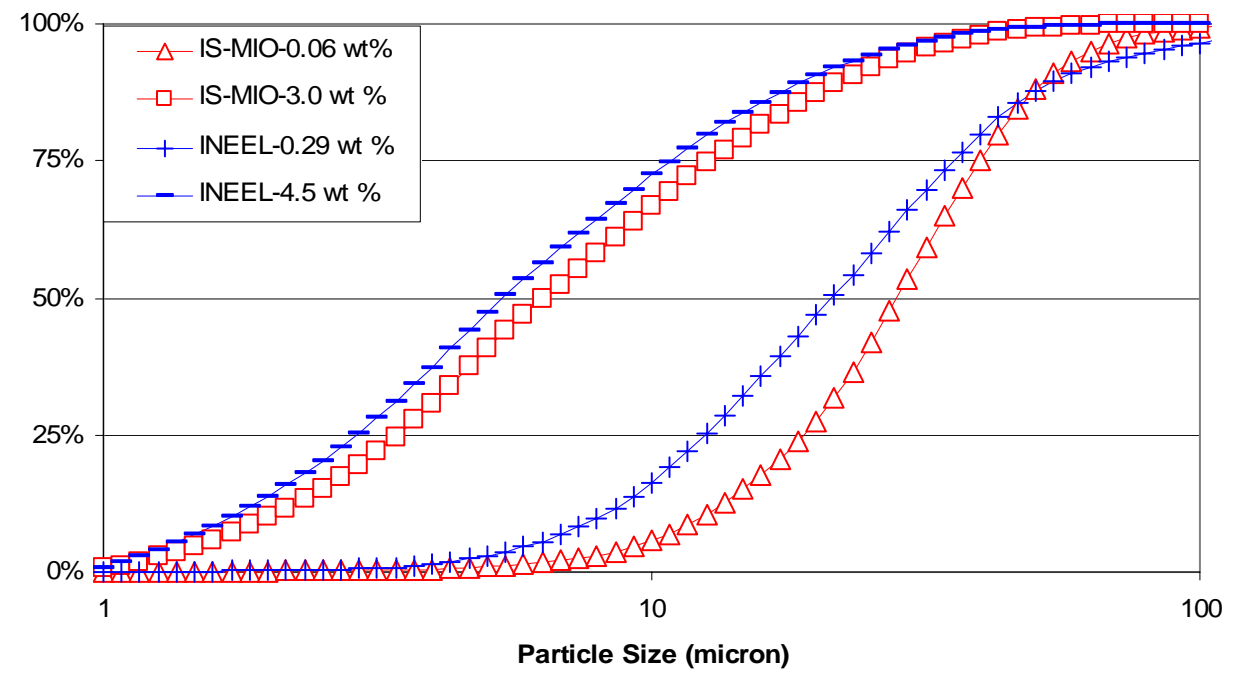

Figure 11. Comparison of Particle Size during 0.1 Micron Filter Test 


\section{Actual Waste Decontamination Testing}

\section{Plutonium Results}

The composite used in these experiments includes waste from Tank $39 \mathrm{H}$, which is very high in ${ }^{238} \mathrm{Pu}$. While there are detectable amounts of ${ }^{239 / 240} \mathrm{Pu}$ in the solution, we report only the ${ }^{238} \mathrm{Pu}$ results due to superior analytical resolution. Figure 12 displays the graphical trends. The time $=0$ results represent samples taken before the addition of any sorbents.

The control data is stable over the period of the entire experiment, indicating that the plutonium concentration reached equilibrium before the start, and during the length of the experiments (the tabular data is listed in Appendix B). The $0.17 \mathrm{~g} / \mathrm{L} \mathrm{Fe} \mathrm{IS-MIO} \mathrm{duplicate} \mathrm{experiments} \mathrm{show} \mathrm{good}$ agreement in the plutonium behavior, except for the 1 hour data point for the duplicate. Both data sets show an initial high DF (Table 3), followed by a decline over time, indicating desorption of plutonium. This desorption means that a facility outage occurring before filtration can lead to poor batch performance. The initial high DF values in this experiment are less than seen in the results of previous simulant tests by ANL, possibly due to differences in the form of the plutonium species between actual and simulant waste. However, the magnitude of the decline in DF $(\sim 75 \%)$ is the same as observed in the most recent set of ANL tests.

The MST experiment, as expected, did not show the same sort of desorption behavior exhibited in the $0.17 \mathrm{~g} / \mathrm{L}$ IS-MIO experiments. At the end of 24 hours, the MST experiment gave a DF of $>6.4$, which is comparable to previous MST experiments. ${ }^{18}$

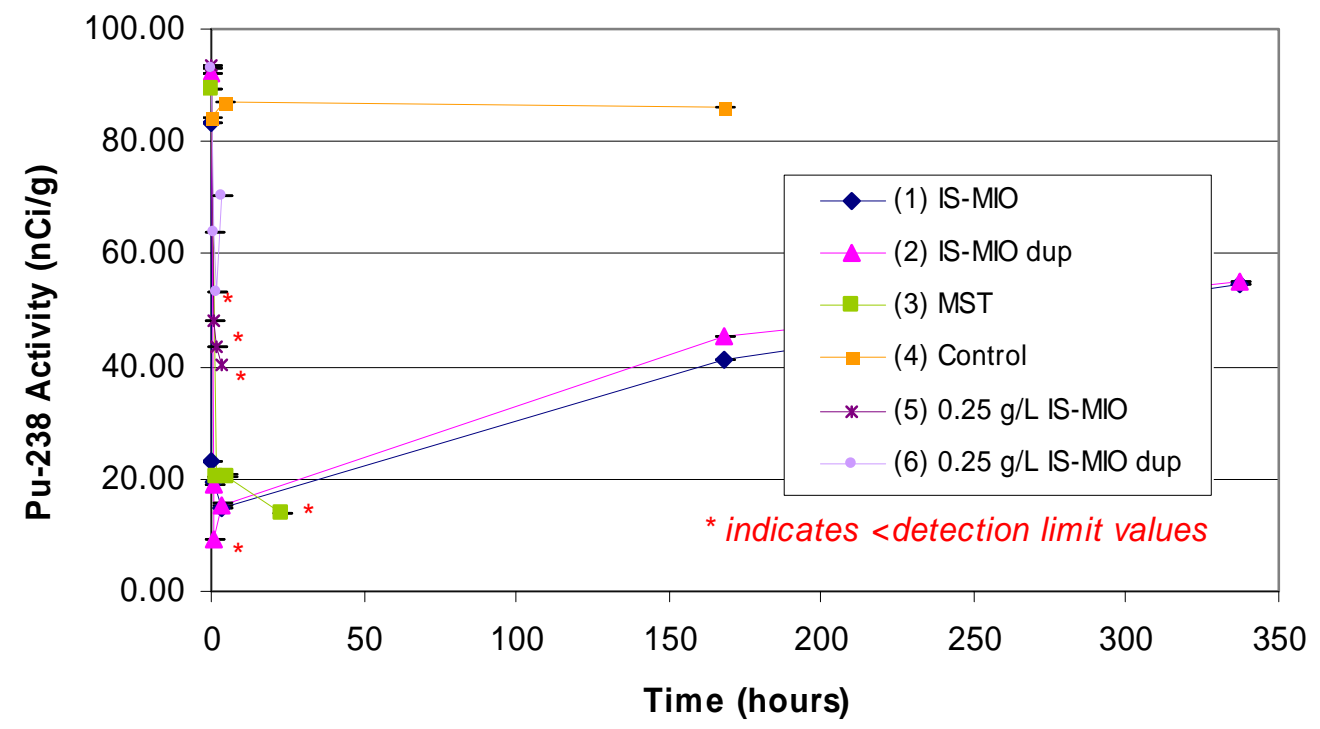

Figure 12. Plutonium Concentrations in Solution 
Researchers performed the $0.25 \mathrm{~g} / \mathrm{L}$ IS-MIO experiments in hopes of seeing a slightly better plutonium removal behavior. Technicians collected samples at 0 (i.e., before the iron strike), 1 , 2 and 4 hours after the iron strike, giving fewer data points than the original IS-MIO experiments. The results of these experiments showed much poorer Pu removal. ${ }^{8,9}$ Figure 13 shows the sample results between 0 and 30 hours.

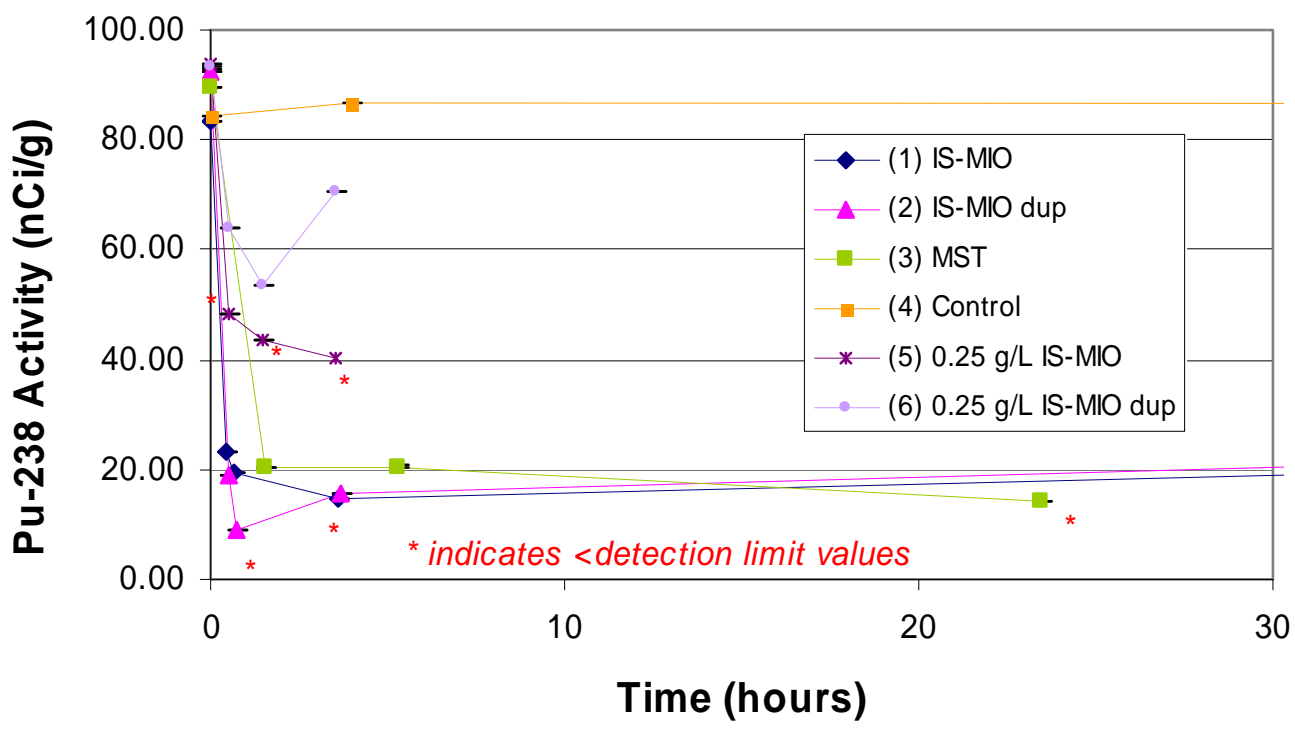

Figure 13. Plutonium Concentrations in Solution from 0 to 30 Hours

We partially attribute the poor Pu removal behavior of the $0.25 \mathrm{~g} / \mathrm{L}$ IS-MIO tests to poorer stirring. Due to requirements for other programs to use the water bath/stirrer unit, the $0.25 \mathrm{~g} / \mathrm{L}$ IS-MIO tests used a conventional magnetic stirrer unit. The technicians noted that during these tests, the bottles exhibited poor stirring behavior (i.e., the stir bars tended to bound around instead of rotating) despite attempts to control the stirring. 
Table 3. Plutonium DF Values from the Non-Control Experiments

\begin{tabular}{|c|c|c|c|c|c|c|}
\hline $\begin{array}{c}\text { Time } \\
(\mathrm{h})\end{array}$ & $\begin{array}{c}0.17 \mathrm{~g} / \mathrm{L} \\
\text { Fe } \\
\text { IS-MIO }\end{array}$ & $\begin{array}{c}0.17 \mathrm{~g} / \mathrm{L} \mathrm{Fe} \\
\text { IS-MIO } \\
\text { duplicate }\end{array}$ & $\begin{array}{c}\text { Pereira } \\
\text { Simulant } \\
\text { Test }\end{array}$ & MST & $\begin{array}{c}0.25 \mathrm{~g} / \mathrm{L} \\
\text { Fe IS-MIO }\end{array}$ & $\begin{array}{c}0.25 \mathrm{~g} / \mathrm{L} \\
\text { Fe IS-MIO } \\
\text { duplicate }\end{array}$ \\
\hline 0 & NA & NA & NA & NA & NA & NA \\
\hline $1 / 2$ & 3.61 & 4.85 & 37 & NA & NA & NA \\
\hline 1 & 4.27 & $>10$ & 30 & NA & $>1.95$ & 1.46 \\
\hline 2 & NA & NA & NA & 4.4 & $>2.14$ & 1.74 \\
\hline 4 & 5.63 & 5.95 & NA & NA & $>2.33$ & 1.32 \\
\hline 6 & NA & NA & NA & 4.3 & NA & NA \\
\hline 12 & NA & NA & NA & NA & NA & NA \\
\hline 24 & NA & NA & NA & $>6.4$ & NA & NA \\
\hline 48 & NA & NA & 11 & NA & NA & NA \\
\hline 168 & 2.01 & 2.03 & NA & NA & NA & NA \\
\hline 336 & 1.52 & 1.68 & NA & NA & NA & NA \\
\hline
\end{tabular}

"NA" means not available.

\section{Strontium Results}

The high concentration of ${ }^{90} \mathrm{Sr}$ in the actual waste composite allowed for ease in radiochemical analyses. Figures 14 and 15 display the graphical trends. The time $=0$ results are from samples collected before addition of any sorbents.

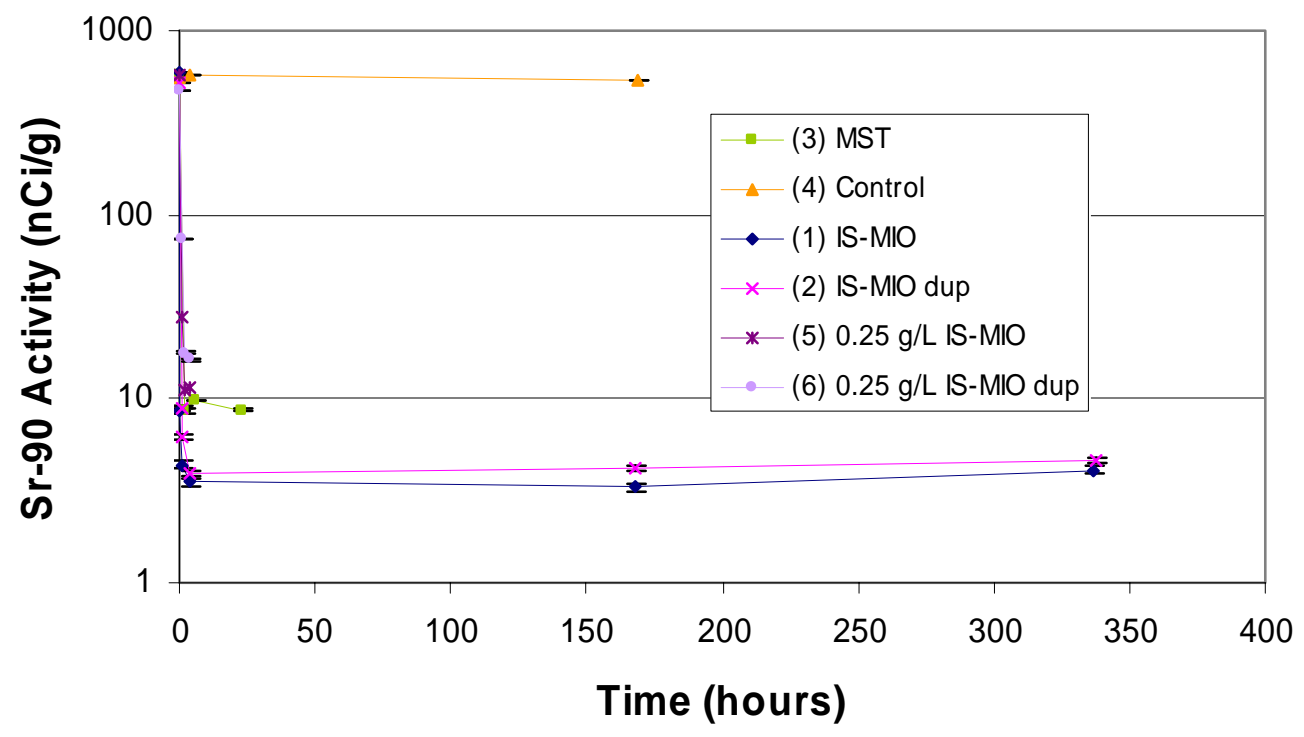

Figure 14. Strontium Concentrations in Solution

As with the plutonium control data, the strontium control data clearly indicates that the strontium reached chemical equilibrium before the start and throughout the length of the experiments (the 
tabular data is listed in Appendix B). The $0.17 \mathrm{~g} / \mathrm{L} \mathrm{Fe} \mathrm{IS-MIO} \mathrm{duplicate} \mathrm{experiments} \mathrm{show} \mathrm{good}$ agreement with each other, as well as an immediate decline in strontium in solution, with no apparent desorption, out to one week. Over time, there is a slight increase in DF. The average two week DF for the strontium is 128. In comparison, the previous IS-MIO simulant experiments by ANL show a two day DF of 39.3. However, both the ANL data set and this data show an increase over time (i.e., $15 \%$ for this data, Table 4, while the ANL data shows a 39\% increase).

The MST experiment produced the expected results. At the end of 24 hours, the MST experiment gave a DF of 66.5, which is comparable to previous MST experiments.

Researchers performed the $0.25 \mathrm{~g} / \mathrm{L}$ Fe IS-MIO experiments in hopes of seeing a slightly better strontium removal behavior. Technicians collected samples at 0 (i.e., before the iron strike), 1, 2 and 4 hours after the iron strike, giving fewer data points than the original IS-MIO experiments. The results indicated a much poorer Sr removal. The $0.25 \mathrm{~g} / \mathrm{L} \mathrm{Fe} \mathrm{IS-MIO} \mathrm{experiments} \mathrm{gave} \mathrm{an}$ average 4 hour strontium DF of 39.5, compared to the original IS-MIO experiment's average DF of 149. As with the plutonium results, we partially attribute the poor Sr removal behavior of the $0.25 \mathrm{~g} / \mathrm{L}$ IS-MIO tests to poorer stirring.

Figure 15 shows the sample results between 0 and 30 hours.

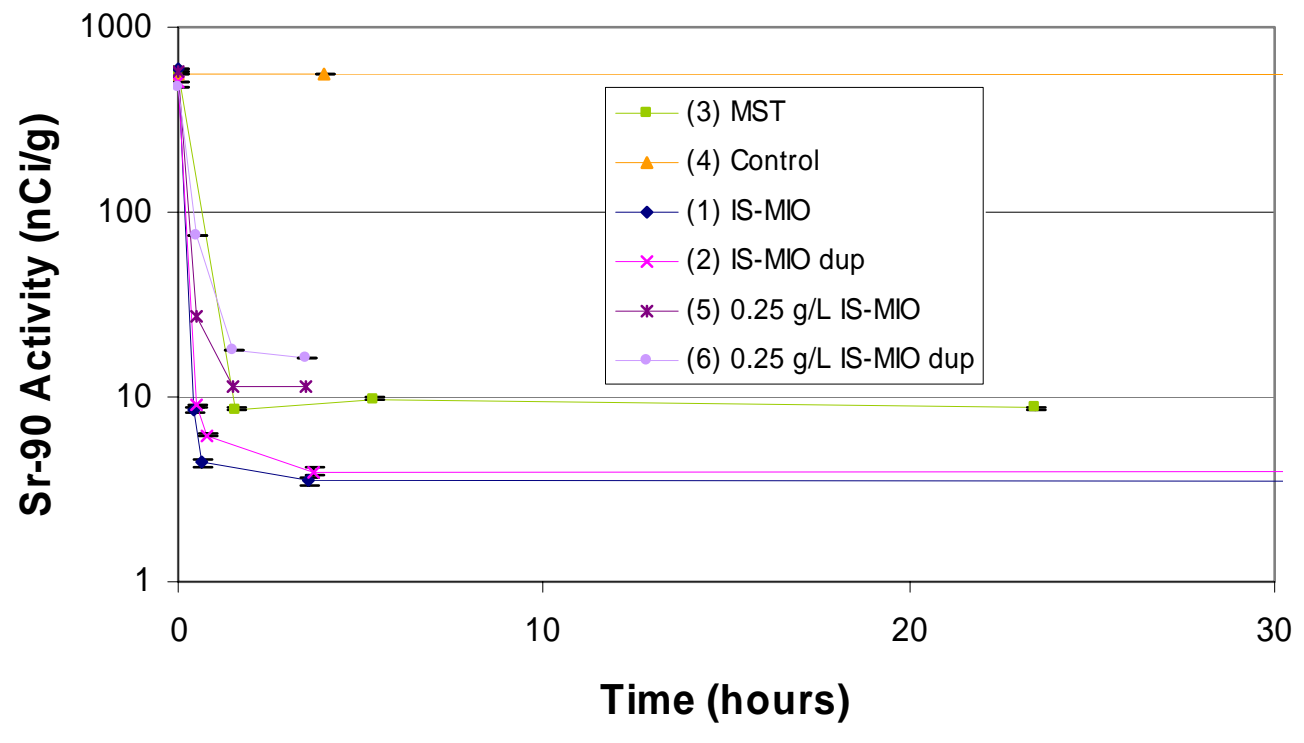

Figure 15. Strontium Concentrations in Solution from 0 to 30 Hours 
Table 4. Strontium DF Values from the Non-Control Experiments

\begin{tabular}{|c|c|c|c|c|c|c|}
\hline $\begin{array}{c}\text { Time } \\
\text { h) }\end{array}$ & $\begin{array}{c}0.17 \mathrm{~g} / \mathrm{L} \\
\text { Fe } \\
\text { IS-MIO }\end{array}$ & $\begin{array}{c}0.17 \mathrm{~g} / \mathrm{L} \mathrm{Fe} \\
\text { IS-MIO } \\
\text { duplicate }\end{array}$ & $\begin{array}{c}\text { Pereira } \\
\text { Simulant } \\
\text { Test }\end{array}$ & MST & $\begin{array}{c}0.25 \mathrm{~g} / \mathrm{L} \\
\text { Fe IS-MIO }\end{array}$ & $\begin{array}{c}0.25 \\
\text { Fe IS-MIO } \\
\text { duplicate }\end{array}$ \\
\hline 0 & NA & NA & NA & NA & NA & NA \\
\hline $1 / 2$ & 69.4 & 57.2 & 18.2 & NA & NA & NA \\
\hline 1 & 135 & 82.5 & 28.1 & NA & 21.0 & 6.38 \\
\hline 2 & NA & NA & NA & 67.4 & 51.4 & 26.5 \\
\hline 4 & 167 & 130 & NA & NA & 49.7 & 29.3 \\
\hline 6 & NA & NA & NA & 59.4 & NA & NA \\
\hline 12 & NA & NA & NA & NA & NA & NA \\
\hline 24 & NA & NA & NA & 66.5 & NA & NA \\
\hline 48 & NA & NA & 39.3 & NA & NA & NA \\
\hline 168 & 178 & 122 & NA & NA & NA & NA \\
\hline 336 & 144 & 111 & NA & NA & NA & NA \\
\hline
\end{tabular}

\section{Neptunium Results}

The actual waste composite did not contain a high concentration of neptunium. Accordingly, the authors realized that the neptunium in solution might fall below instrument detection limits during the experiments. Figure 16 displays the graphical trends. The time $=0$ results are for samples collected before the addition of any sorbents.

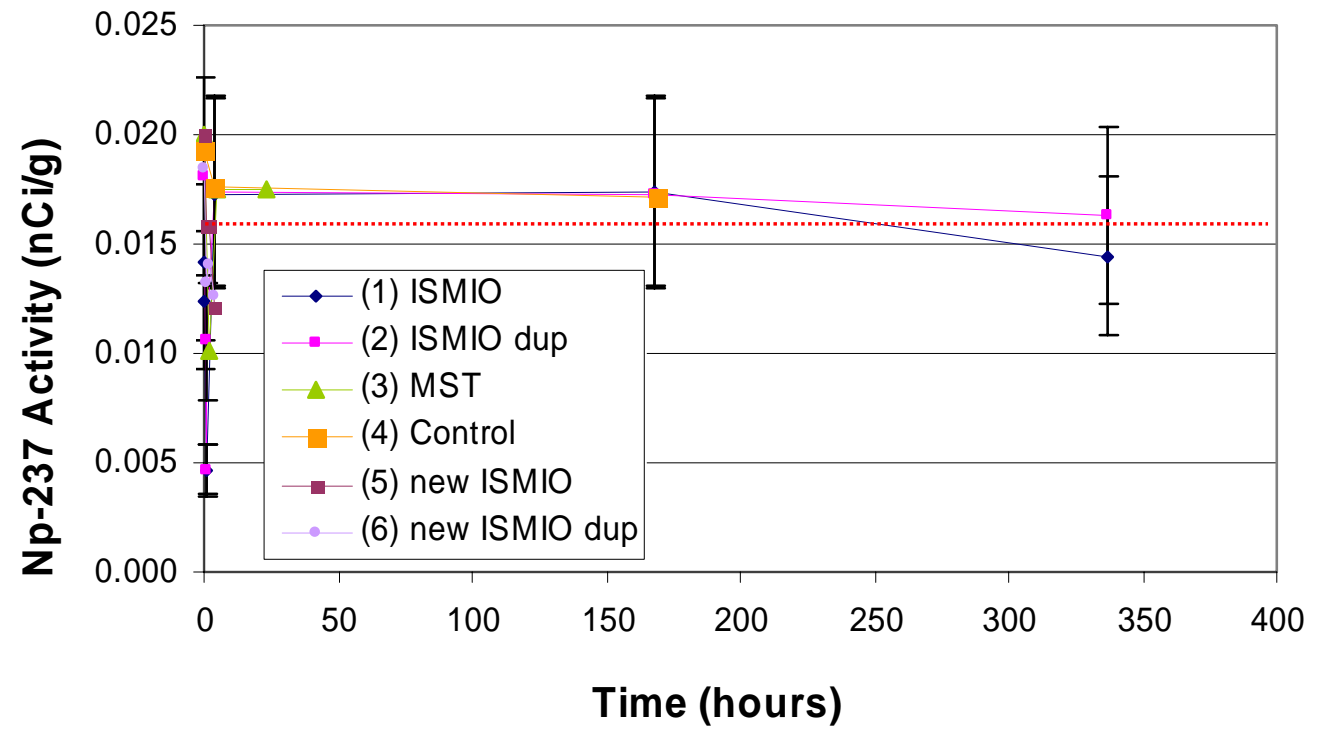

Figure 16. Neptunium Concentration in Solution 
Due to the multiple data points that are less than instrument detection limits, it is very problematic to interpret the neptunium behavior (the tabular data is listed in Appendix B). This makes any DF values tentative at best. For example, the control experiment drops below the detection limit after the first sample. The red dashed line in Figure 16 shows the approximate upper detection limits. In the $0.17 \mathrm{~g} / \mathrm{L}$ iron IS-MIO experiments, while the neptunium in solution starts above detection limit, it hovers right near the limit throughout the experiments, and in some cases, falls below it. It appears that early after the addition of the iron ( $<1$ hour), some neptunium is removed from solution (DF of 3-4, Table 5). However, soon after, and for the rest of the experimental duration, the DF drops to $\sim 1$.

In the MST experiment, the neptunium drops below detection limits after the second sample, giving a DF >1.14 after 24 hours. The detection limit issues make a comparison to previous MST work difficult, but it is likely the DF is in the same approximate range as previous work $(\sim 3-5)$.

In the $0.25 \mathrm{~g} / \mathrm{L} \mathrm{Fe}$ IS-MIO experiments, all of the data points remained above the detection limits, providing a clearer perspective on IS-MIO effects on neptunium (the detection limits for ICP-MS can vary day by day and depending on the number of samples run on it recently). In this case, the duplicates showed good agreement. The duplicates showed an initial average DF of $\sim 1.3$, climbing slightly after 4 hours, to an average DF of $\sim 1.6$. Unfortunately, there is no direct comparison from the ANL work.

Table 5. Neptunium DF Values from the Non-Control Experiments

\begin{tabular}{|c|c|c|c|c|c|}
\hline $\begin{array}{c}\text { Time } \\
(\mathrm{h})\end{array}$ & $\begin{array}{c}0.17 \mathrm{~g} / \mathrm{L} \\
\text { Fe } \\
\text { IS-MIO }\end{array}$ & $\begin{array}{c}0.17 \mathrm{~g} / \mathrm{L} \mathrm{Fe} \\
\text { IS-MIO } \\
\text { duplicate }\end{array}$ & MST & $\begin{array}{c}0.25 \mathrm{~g} / \mathrm{L} \\
\text { Fe IS-MIO }\end{array}$ & $\begin{array}{c}\text { Fe IS-MIO } \\
\text { duplicate }\end{array}$ \\
\hline 0 & NA & NA & NA & NA & NA \\
\hline $1 / 2$ & 1.14 & 3.85 & NA & NA & NA \\
\hline 1 & 3.04 & 1.71 & NA & 1.26 & 1.40 \\
\hline 2 & NA & NA & 1.98 & 1.26 & 1.32 \\
\hline 4 & $>0.820$ & $>1.04$ & NA & 1.64 & 1.47 \\
\hline 6 & NA & NA & $>1.14$ & NA & NA \\
\hline 12 & NA & NA & NA & NA & NA \\
\hline 24 & NA & NA & $>1.14$ & NA & NA \\
\hline 168 & $>0.816$ & $>1.04$ & NA & NA & NA \\
\hline 336 & 0.984 & 1.11 & NA & NA & NA \\
\hline
\end{tabular}




\section{Uranium Results}

Figure 17 displays the graphical trends while Table 6 lists the DF values. The time $=0$ results are for samples collected before the addition of any sorbents.

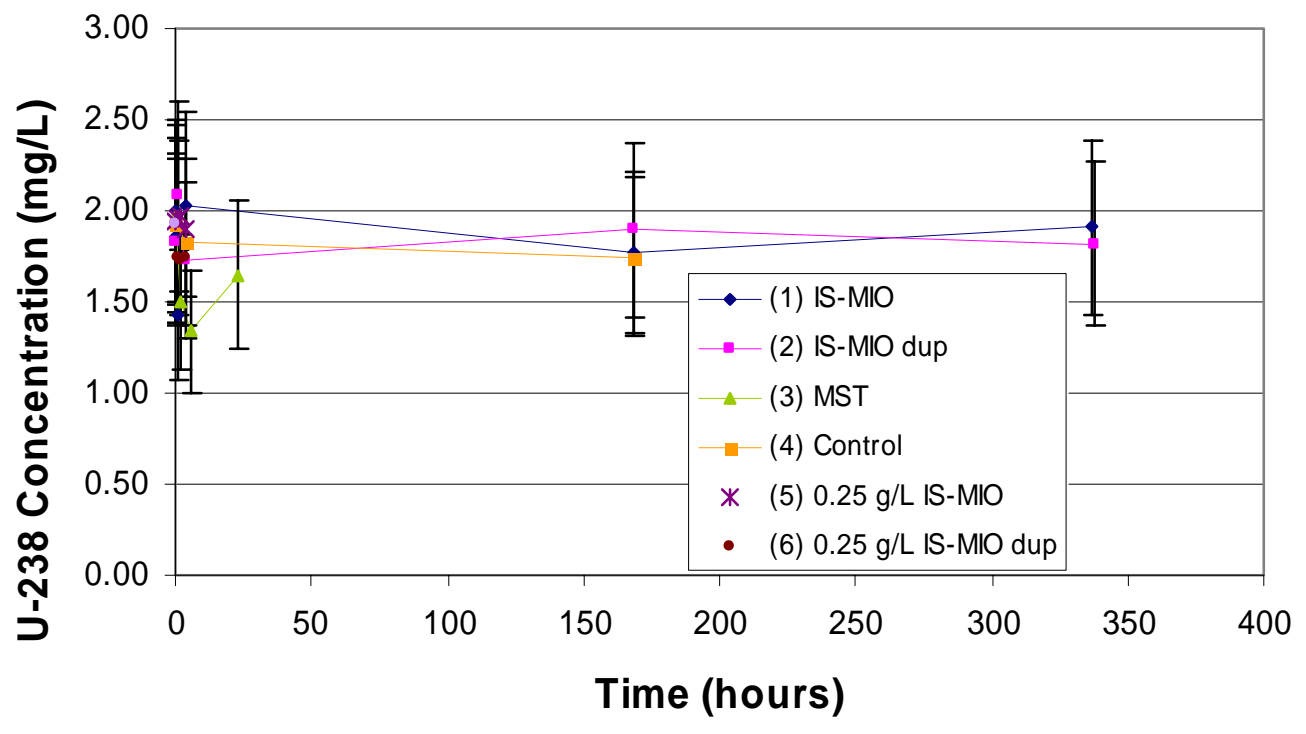

Figure 17. Uranium Concentration in Solution

The control experiment showed that the uranium in solution remained stable throughout the duration of the experiments (the tabular data is listed in Appendix B). However, none of the sorbents had a large effect on the uranium in solution. The $0.17 \mathrm{~g} / \mathrm{L} \mathrm{Fe} \mathrm{IS-MIO} \mathrm{experimental}$ data almost all fell within analytical uncertainty of the starting uranium concentration. Within the limits of analytical certainty, we conclude that uranium in solution is unaffected by the conditions of the $0.17 \mathrm{~g} / \mathrm{L}$ IS-MIO tests. Previous work by ANL did not examine uranium so we have no data to make a comparison.

The MST experiment gave a 24 hour DF of 1.19 (Table 6), comparable to previous results that show a typical uranium DF of 1.3-1.5.

In the $0.25 \mathrm{~g} / \mathrm{L}$ Fe IS-MIO experiments, the data shows virtually no effect on uranium in solution. In all cases, the uranium data points after the addition of the iron fall within the analytical uncertainty range of the uranium before the addition of iron. This allows us to conclude that IS-MIO under the reaction conditions has no effect on uranium. 
Table 6. Uranium DF Values from the Non-Control Experiments

\begin{tabular}{|c|c|c|c|c|c|}
\hline $\begin{array}{c}\text { Time } \\
(\mathrm{h})\end{array}$ & $\begin{array}{c}0.17 \mathrm{~g} / \mathrm{L} \\
\text { Fe } \\
\text { IS-MIO }\end{array}$ & $\begin{array}{c}0.17 \mathrm{~g} / \mathrm{L} \text { Fe } \\
\text { IS-MIO } \\
\text { duplicate }\end{array}$ & MST & $\begin{array}{c}0.25 \mathrm{~g} / \mathrm{L} \\
\text { Fe IS-MIO }\end{array}$ & $\begin{array}{c}\text { Fe IS-MIO } \\
\text { duplicate }\end{array}$ \\
\hline 0 & NA & NA & NA & NA & NA \\
\hline $1 / 2$ & 1.08 & 0.88 & NA & NA & NA \\
\hline 1 & 1.40 & 0.96 & NA & 1 & 1.11 \\
\hline 2 & NA & NA & 1.31 & 0.98 & 1.12 \\
\hline 4 & 0.99 & 1.06 & NA & 1.03 & 1.10 \\
\hline 6 & NA & NA & 1.47 & NA & NA \\
\hline 12 & NA & NA & NA & NA & NA \\
\hline 24 & NA & NA & 1.19 & NA & NA \\
\hline 168 & 1.13 & 0.97 & NA & NA & NA \\
\hline 336 & 1.05 & 1.01 & NA & NA & NA \\
\hline
\end{tabular}

\section{IS-MIO Applicability for the ARP and SWPF Processes}

The results of the studies in this document confirm the filtration cycle are identical to those used for MST. Furthermore, the DF values achieved by IS-MIO are comparable to those for MST. A previous flowsheet document listed the conditions and prerequisites for the IS-MIO process. ${ }^{19}$ However, the process assumptions (the amount of iron used, for example) from the document differ in some cases from our reaction conditions. At this time, we believe that the differences will not result in a change in conclusions, although a technical review of these differences should be done in the future. The experiments did not give insight into the filter cleaning requirements for the IS-MIO solids.

SRNL believes that the conditions and conclusion for the SWPF are analogous to those of the ARP. 


\section{Technology Risk Assessment}

The IS-MIO process is not a fully mature technology. While personnel completed a number of simulant tests and some actual waste tests, further work is needed to mature this process. Current technology risks include the following.

- Lack of filtration demonstration at pilot scale and for longer durations

- Lack of filtration studies using actual waste

- Uncertainty about the shelf life (i.e., chemical stability) of the Fe(II) reagent

- Absence of data for long term rheology

- Lack of data during washing/desorption studies with actual waste

- Lack of vitrification data

- Lack of understanding of cause of DF loss over time.

\section{Cost of Implementation of IS-MIO}

IS-MIO offers a cost reduction in reagent use. IS-MIO reagent batch costs are approximately one fifth those of MST. The IS-MIO costs in Table 7 come from a Sigma-Aldrich quote. ${ }^{20}$ However, IS-MIO will require one additional chemical storage tank. One tank will contain the Fe(III) solution while another tank contains the Fe(II) solution. Streams from each tank can be combined into a single stream before entry into the radiological facility. No changes in equipment internal to the cells are anticipated. The existing ARP facility can likely accommodate these needs with minor changes in cold feeds equipment and procedures.

Table 7. Comparative Reagent Cost

\begin{tabular}{|c|c|c|c|}
\hline $\begin{array}{c}\text { Chemical } \\
\text { MST process }\end{array}$ & $\begin{array}{c}\text { Mass Needed } \\
\text { (g/L of waste) }\end{array}$ & Unit Cost $\mathbf{( \$ / g )}$ & $\begin{array}{c}\text { Batch Cost } \\
\text { (\$/L of waste) }\end{array}$ \\
\hline $\mathrm{MST}^{1}$ & & & \\
\hline & 0.4 & 125 & 0.103 \\
\hline \multicolumn{1}{|c|}{ IS-MIO Process $\left.\mathrm{NO}_{3}\right)_{3} \cdot 9 \mathrm{H}_{2} \mathrm{O}$} & & & \\
\hline $\mathrm{FeSO}$ & & & \\
\hline $0.4 \mathrm{M} \mathrm{H}_{2} \mathrm{O} \mathrm{SO}_{4}{ }^{2}$ & 0.72 & 0.0179 & 0.0129 \\
\hline IS-MIO total & 0.50 & 0.00726 & 0.00363 \\
\hline
\end{tabular}

${ }^{1}$ MST data from WSRC-RP-2002-00524, Rev 0, table V.

${ }^{2}$ Assumes $0.4 \mathrm{M}$ solution for the Fe(II) species. Diluted from 18.5 M concentrated acid. 


\section{CONCLUSIONS}

The conclusions from this work follow.

- The IS-MIO solids do not produce an increase in filter flux. The increased flux observed in some comparisons is due to differences in operating conditions rather than to improved filterability of the IS-MIO solids.

- Filter flux with sludge and IS-MIO solids increases with increasing axial velocity. A similar correlation occurred with sludge and MST solids.

- The IS-MIO particles are initially larger than MST particles. Because of shear, by the end of the test, the IS-MIO solids were approximately the same size as MST solids.

- An initial plutonium Decontamination Factor (DF) of $\sim 7$ resulted. This declined to a DF of $\sim 1.6$ over a period of two weeks.

- An initial strontium DF of $\sim 110$ occurred. This increased to a DF of $\sim 128$ after a period of two weeks. In comparison, MST provided a DF of $\sim 67$.

- The IS-MIO process provided no significant removal of uranium from solution. 
Rev. 0

\section{APPENDIX A STATISTICAL ANALYSES}

\section{IS-MIO 0.06 wt \% Statistics}

\section{Whole Model}

Summary of Fit

RSquare

0.674335

0.592919

$\begin{array}{lr}\text { Root Mean Square Error } & 0.007994 \\ \text { Mean of Response } & 0.06736\end{array}$

Observations (or Sum Wgts)

Analysis of Variance

$\begin{array}{lr}\text { Source } & \text { DF } \\ \text { Model } & 2 \\ \text { Error } & 8 \\ \text { C. Total } & 10\end{array}$

Sum of Squares 0.00105857

0.00051123

0.00156979

Parameter Estimates

$\begin{array}{lrr}\text { Term } & \text { Estimat } \\ \text { Intercept } & 0.0222021 \\ \text { TMP } & 0.0005555 \\ \text { Velocity } & 0.0031539 \\ \text { Effect Tests } & \\ \text { Source } & \text { Nparm } & \text { DF } \\ \text { TMP } & 1 & 1 \\ \text { Velocity } & 1 & 1\end{array}$

$\begin{array}{rrr}\text { Std Error } & \text { t Ratio } & \text { Prob }>|t| \\ 0.01187 & 1.87 & 0.0983 \\ 0.000277 & 2.00 & 0.0800 \\ 0.000886 & 3.56 & 0.0074\end{array}$

F Ratio

Mean Square 0.000529 8.2826 Prob $>$ F 0.0112

\section{IS-MIO 3.0 wt \% Statistics}

\section{Whole Model}

\section{Summary of Fit}

RSquare

RSquare Adj

0.830918

Root Mean Square Error

Mean of Response

Observations (or Sum Wgts)

Analysis of Variance

$\begin{array}{lr}\text { Source } & \text { DF } \\ \text { Model } & 2 \\ \text { Error } & 8 \\ \text { C. Total } & 10\end{array}$

\section{Parameter Estimates}

Term

Intercept

TMP 2

Velocity 2

Effect Tests

Source

TMP 2

Velocity 2

\subsection{8}

0.002336

0.018502

$$
11
$$

$$
\begin{array}{rrr}
\text { Sum of Squares } & \text { Mean Square } & \text { F Ratio } \\
0.00021454 & 0.000107 & 19.6572 \\
0.00004366 & 0.000005 & \text { Prob }>\text { F } \\
0.00025820 & & 0.0008
\end{array}
$$

Prob > F 0.0800 0.0074
Estimate Std Error t Ratio Prob $>1 \mathrm{t}$ $\begin{array}{llll}-0.00265 & 0.003945 & -0.67 & 0.5207\end{array}$ $\begin{array}{llll}0.000108 & 0.000081 & 1.34 & 0.2174\end{array}$ $\begin{array}{llll}0.0021073 & 0.000342 & 6.17 & 0.0003\end{array}$ Nparm DF

$\begin{array}{ll}1 & 1 \\ 1 & 1\end{array}$

Sum of Squares 0.00000978 0.00020754
F Ratio

1.7928 38.0310
Prob $>\mathrm{F}$
0.2174
0.0003 
Rev. 0

Comparison of Flux with IS-MIO at 0.06 wt $\%$ and MST at 0.29 wt \%

Response 0.06 wt \% Flux (IS-MIO vs. MST)

Whole Model

Actual by Predicted Plot

\section{Summary of Fit}

RSquare

RSquare Adj

Root Mean Square Error

Mean of Response

Observations (or Sum Wgts)

Analysis of Variance

$$
\begin{aligned}
& 0.699012 \\
& 0.648847 \\
& 0.009541 \\
& 0.059623
\end{aligned}
$$

Source

Model

$\begin{array}{rr}\text { DF } & \text { Sum of Squares } \\ 3 & 0.00380576 \\ 18 & 0.00163872 \\ 21 & 0.00544448\end{array}$

Error

C. Total

21

\section{Lack Of Fit}

Source

Lack Of Fit

Pure Error

Total Error

DF

$\begin{array}{rr}\text { Mean Square } & \text { F Ratio } \\ 0.001269 & 13.9344 \\ 0.000091 & \text { Prob }>\text { F } \\ & <.0001\end{array}$

$$
\begin{array}{rr}
\text { Mean Square } & \text { F Ratio } \\
0.000069 & 0.2592 \\
0.000267 & \text { Prob }>\text { F } \\
& 0.9571 \\
& \text { Max RSq } \\
& 0.9021
\end{array}
$$

Parameter Estimates

Term

Intercept

Feed[INEEL]

Velocity 3

TMP 3

Estimate
0.0133035
-0.007709
0.0035665
0.000473

Std Error
0.009894
0.002035
0.000739
0.000233

t Ratio
1.34
-3.79
4.83
2.03

Prob $>|t|$

0.1954

0.0013

0.0001

Effect Tests

Source

Feed

Velocity 3

TMP 3

$\begin{array}{rr}\text { Nparm } & \text { DF } \\ 1 & 1 \\ 1 & 1 \\ 1 & 1\end{array}$

F Ratio

14.3568

23.2894

4.1381
Prob $>\mathrm{F}$ 0.0013

0.0001

0.0569

\section{Feed}

Least Squares Means Table

Level

INEEL

Least Sq Mean

0.05191389

IS-MIO

0.06733156 
Rev. 0

Comparison of Flux with IS-MIO at 3 wt \% and MST at 4.5 wt \%

Response 4.5 wt \% Flux (IS-MIO vs. MST)

Whole Model

Summary of Fit

RSquare

0.806677

RSquare Adj

0.774456

Root Mean Square Error $\quad 0.005984$

Mean of Response 0.025505

Observations (or Sum Wgts)

Analysis of Variance

Source

Model

DF

Error

3

18

C. Total

21

Sum of Squares

0.00268923

0.00064448

0.00333371

Mean Square
0.000896
0.000036

Sum of Squares

0.00042656

0.00021793

Lack Of Fit

Pure Error

Total Error

DF
16
2
18

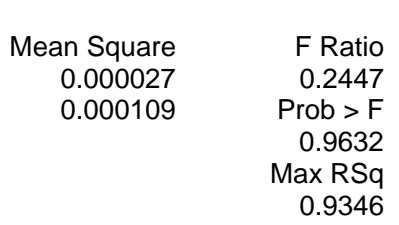

Parameter Estimates

Term

Intercept

Feed 2[INEEL]

Velocity 4

TMP 4

Effect Tests

Source

Feed 2

Velocity 4

TMP 4

Estimate
-0.008687
0.006124
0.0034629
0.0001302

Nparm DF

$\begin{array}{ll}1 & 1 \\ 1 & 1 \\ 1 & 1\end{array}$

Feed 2

Least Squares Means Table

Level

INEEL

Least Sq Mean

0.03162858

0.01938051

$\begin{array}{rr}\text { Std Error } & \text { Mean } \\ 0.00181104 & 0.032509 \\ 0.00181104 & 0.018500\end{array}$

0.032509
IS-MIO
Std Error
0.006527
0.001285
0.000146
Sum of Squares
0.00081266
0.00158782
0.00002863

0.00181104
F Ratio

25.0361

Prob $>$ F

$<.0001$

ob $>\mathrm{F}$

0.9632

0.9346

$\begin{array}{rr}\text { t Ratio } & \text { Prob }>|t| \\ -1.33 & 0.1998 \\ 4.76 & 0.0002 \\ 6.66 & <.0001 \\ 0.89 & 0.3830\end{array}$

$\begin{array}{rr}\text { F Ratio } & \text { Prob > F } \\ 22.6970 & 0.0002 \\ 44.3468 & <.0001 \\ 0.7996 & 0.3830\end{array}$


Rev. 0

\section{Comparison of IS-MIO and MST during Concentration of Solids}

Oneway Analysis of Flux By Test

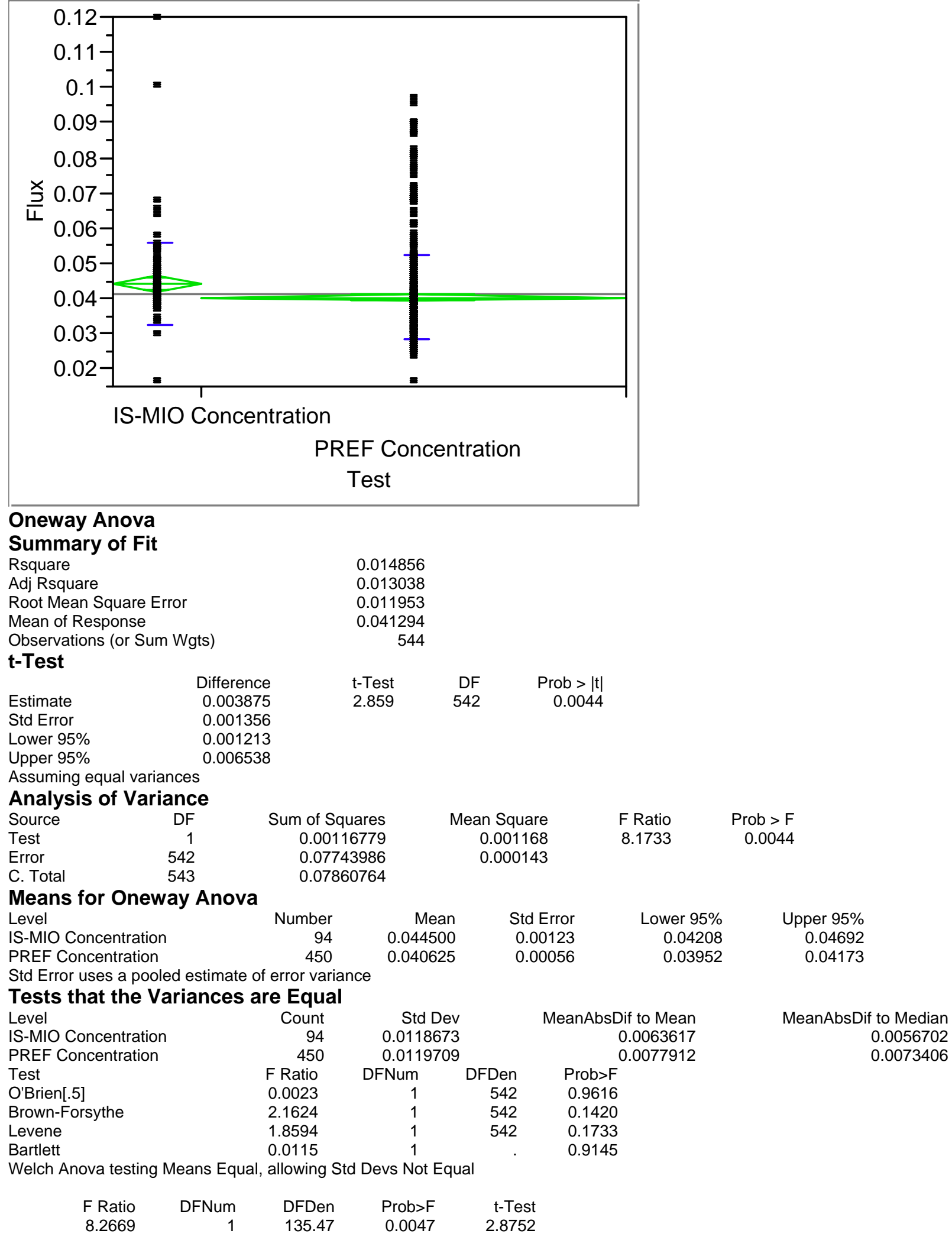




\section{Appendix B. Raw Data for Actual Waste Tests}

\section{Plutonium-238 Data}

\begin{tabular}{|c|c|c|c|c|c|c|}
\hline $\begin{array}{l}\text { Time } \\
\text { (h) }\end{array}$ & $\begin{array}{c}0.17 \mathrm{~g} / \mathrm{L} \mathrm{Fe} \\
\text { IS-MIO } \\
\text { (\%uncert) }\end{array}$ & $\begin{array}{c}0.17 \mathrm{~g} / \mathrm{L} \mathrm{Fe} \\
\text { IS-MIO } \\
\text { duplicate } \\
\text { (\%uncert) }\end{array}$ & $\begin{array}{c}\text { MST } \\
\text { (\%uncert) }\end{array}$ & $\begin{array}{c}\text { Control } \\
\text { (\%uncert) }\end{array}$ & $\begin{array}{c}0.25 \mathrm{~g} / \mathrm{L} \mathrm{Fe} \\
\text { IS-MIO } \\
\text { (\%uncert) }\end{array}$ & $\begin{array}{c}0.25 \mathrm{~g} / \mathrm{L} \\
\text { Fe IS-MIO } \\
\text { duplicate } \\
\text { (\%uncert) }\end{array}$ \\
\hline 0 & $\begin{array}{c}8.33 \mathrm{E}+01 \\
(4.70 \%)\end{array}$ & $\begin{array}{c}9.22 \mathrm{E}+01 \\
(4.40 \%)\end{array}$ & $\begin{array}{c}8.94 \mathrm{E}+01 \\
(4.80 \%)\end{array}$ & $\begin{array}{c}8.42 \mathrm{E}+01 \\
(4.70 \%)\end{array}$ & $\begin{array}{l}9.37 \mathrm{E}+01 \\
*(4.55 \%)\end{array}$ & $\begin{array}{l}9.31 \mathrm{E}+01 \\
*(4.50 \%)\end{array}$ \\
\hline $1 / 2$ & $\begin{array}{c}2.31 \mathrm{E}+01 \\
(4.70 \%)\end{array}$ & $\begin{array}{c}1.90 \mathrm{E}+01 \\
(5.10 \%)\end{array}$ & NA & NA & NA & NA \\
\hline 1 & $\begin{array}{c}1.95 \mathrm{E}+01 \\
(5.00 \%)\end{array}$ & $\begin{array}{c}<9.07 \mathrm{E}+00 \\
(\mathrm{MDL})\end{array}$ & NA & NA & $\begin{array}{c}<4.81 \mathrm{E}+01 \\
(\mathrm{MDL})\end{array}$ & $\begin{array}{c}6.39 \mathrm{E}+01 \\
(4.50 \%)\end{array}$ \\
\hline 2 & NA & NA & $\begin{array}{c}2.02 \mathrm{E}+01 \\
(4.90 \%)\end{array}$ & NA & $\begin{array}{c}<4.37 \mathrm{E}+01 \\
(\mathrm{MDL})\end{array}$ & $\begin{array}{c}5.34 \mathrm{E}+01 \\
(4.60 \%)\end{array}$ \\
\hline 4 & $\begin{array}{c}1.48 \mathrm{E}+01 \\
(5.00 \%)\end{array}$ & $\begin{array}{c}1.55 \mathrm{E}+01 \\
(4.30 \%)\end{array}$ & NA & $\begin{array}{c}8.69 \mathrm{E}+01 \\
(4.60 \%)\end{array}$ & $\begin{array}{l}<4.03 \mathrm{E}+01 \\
(\mathrm{MDL})\end{array}$ & $\begin{array}{c}7.04 \mathrm{E}+01 \\
(4.40 \%)\end{array}$ \\
\hline 6 & NA & NA & $\begin{array}{c}2.06 \mathrm{E}+01 \\
(4.60 \%)\end{array}$ & NA & NA & NA \\
\hline 12 & NA & NA & NA & NA & NA & NA \\
\hline 24 & NA & NA & $\begin{array}{l}<1.40 \mathrm{E}+01 \\
(\mathrm{MDL})\end{array}$ & NA & NA & NA \\
\hline 168 & $\begin{array}{c}4.14 \mathrm{E}+01 \\
(4.80 \%)\end{array}$ & $\begin{array}{c}4.55 \mathrm{E}+01 \\
(4.70 \%)\end{array}$ & NA & $\begin{array}{c}8.61 \mathrm{E}+01 \\
(4.70 \%)\end{array}$ & NA & NA \\
\hline 336 & $\begin{array}{c}5.47 \mathrm{E}+01 \\
(4.80 \%)\end{array}$ & $\begin{array}{c}5.49 \mathrm{E}+01 \\
(4.49 \%)\end{array}$ & NA & NA & NA & NA \\
\hline
\end{tabular}

"NA" indicates no analysis occurred for the sample.

"MDL" indicates method detection limit.

“*” indicates that this data point is the simple average of two data points. 
Strontium-90 Data

\begin{tabular}{|c|c|c|c|c|c|c|}
\hline $\begin{array}{l}\text { Time } \\
\text { (h) }\end{array}$ & $\begin{array}{c}0.17 \mathrm{~g} / \mathrm{L} \\
\mathrm{Fe} \\
\text { IS-MIO } \\
\text { (\%uncert) } \\
\end{array}$ & $\begin{array}{c}0.17 \mathrm{~g} / \mathrm{L} \mathrm{Fe} \\
\text { IS-MIO } \\
\text { duplicate } \\
\text { (\%uncert) }\end{array}$ & $\begin{array}{c}\text { MST } \\
\text { (\%uncert) }\end{array}$ & $\begin{array}{c}\text { Control } \\
\text { (\%uncert) }\end{array}$ & $\begin{array}{c}0.25 \mathrm{~g} / \mathrm{L} \\
\text { Fe IS-MIO } \\
\text { (\%uncert) }\end{array}$ & $\begin{array}{c}0.25 \mathrm{~g} / \mathrm{L} \\
\text { Fe IS-MIO } \\
\text { duplicate } \\
\text { (\%uncert) }\end{array}$ \\
\hline 0 & $\begin{array}{c}5.88 \mathrm{E}+02 \\
(8.90 \%)\end{array}$ & $\begin{array}{c}5.14 \mathrm{E}+02 \\
(7.84 \%)\end{array}$ & $\begin{array}{c}5.80 \mathrm{E}+02 \\
(8.40 \%)\end{array}$ & $\begin{array}{c}5.55 \mathrm{E}+02 \\
(9.30 \%)\end{array}$ & $\begin{array}{l}5.76 \mathrm{E}+02 \\
*(8.10 \%)\end{array}$ & $\begin{array}{l}4.75 \mathrm{E}+02 \\
*(8.65 \%)\end{array}$ \\
\hline $1 / 2$ & $\begin{array}{c}8.47 \mathrm{E}+00 \\
(12.1 \%) \\
\end{array}$ & $\begin{array}{c}8.99 \mathrm{E}+00 \\
(11.8 \%)\end{array}$ & NA & NA & NA & NA \\
\hline 1 & $\begin{array}{c}4.37 \mathrm{E}+00 \\
(15.9 \%)\end{array}$ & $\begin{array}{c}6.23 \mathrm{E}+00 \\
(13.8 \%) \\
\end{array}$ & NA & NA & $\begin{array}{c}2.74 \mathrm{E}+01 \\
(9.18 \%)\end{array}$ & $\begin{array}{c}7.45 \mathrm{E}+01 \\
(9.00 \%) \\
\end{array}$ \\
\hline 2 & NA & NA & $\begin{array}{c}8.60 \mathrm{E}+00 \\
(15.8 \%)\end{array}$ & NA & $\begin{array}{c}1.12 \mathrm{E}+01 \\
(10.8 \%)\end{array}$ & $\begin{array}{c}1.79 \mathrm{E}+01 \\
(10.8 \%)\end{array}$ \\
\hline 4 & $\begin{array}{c}3.52 \mathrm{E}+00 \\
(26.4 \%)\end{array}$ & $\begin{array}{c}3.94 \mathrm{E}+00 \\
(19.3 \%)\end{array}$ & NA & $\begin{array}{c}5.66 \mathrm{E}+02 \\
(8.40 \%)\end{array}$ & $\begin{array}{c}1.16 \mathrm{E}+01 \\
(11.2 \%)\end{array}$ & $\begin{array}{c}1.62 \mathrm{E}+01 \\
(11.4 \%)\end{array}$ \\
\hline 6 & NA & NA & $\begin{array}{c}9.76 \mathrm{E}+00 \\
(12.6 \%)\end{array}$ & NA & NA & NA \\
\hline 12 & NA & NA & NA & NA & NA & NA \\
\hline 24 & NA & NA & $\begin{array}{c}8.72 \mathrm{E}+00 \\
(12.3 \%) \\
\end{array}$ & NA & NA & NA \\
\hline 168 & $\begin{array}{c}3.31 \mathrm{E}+00 \\
(25.3 \%)\end{array}$ & $\begin{array}{c}4.23 \mathrm{E}+00 \\
(17.1 \%)\end{array}$ & NA & $\begin{array}{c}5.39 \mathrm{E}+02 \\
(8.40 \%)\end{array}$ & NA & NA \\
\hline 336 & $\begin{array}{c}4.08 \mathrm{E}+00 \\
(18.9 \%)\end{array}$ & $\begin{array}{c}4.64 \mathrm{E}+00 \\
(17.1 \%)\end{array}$ & NA & NA & NA & NA \\
\hline
\end{tabular}

"NA" indicates no analysis for the sample.

"*" indicates that this data point is actually the average of two data points. 


\section{Neptunium-237 Data}

\begin{tabular}{|c|c|c|c|c|c|c|}
\hline $\begin{array}{c}\text { Time } \\
(\mathrm{h})\end{array}$ & $\begin{array}{c}0.17 \mathrm{~g} / \mathrm{L} \\
\mathrm{Fe} \\
\text { IS-MIO }\end{array}$ & $\begin{array}{c}0.17 \mathrm{~g} / \mathrm{L} \text { Fe } \\
\text { IS-MIO } \\
\text { duplicate }\end{array}$ & MST & Control & $\begin{array}{c}0.25 \mathrm{~g} / \mathrm{L} \\
\text { Fe IS-MIO }\end{array}$ & $\begin{array}{c}0.25 \mathrm{~g} / \mathrm{L} \\
\text { Fe IS-MIO } \\
\text { duplicate }\end{array}$ \\
\hline 0 & $1.42 \mathrm{E}-02$ & $1.81 \mathrm{E}-02$ & $1.99 \mathrm{E}-02$ & $1.93 \mathrm{E}-02$ & $2.00 \mathrm{E}-02$ & $1.85 \mathrm{E}-02$ \\
\hline $1 / 2$ & $1.24 \mathrm{E}-02$ & $<4.69 \mathrm{E}-03$ & NA & NA & NA & NA \\
\hline 1 & $<4.67 \mathrm{E}-03$ & $1.06 \mathrm{E}-02$ & NA & NA & $1.59 \mathrm{E}-02$ & $1.32 \mathrm{E}-02$ \\
\hline 2 & NA & NA & $1.01 \mathrm{E}-02$ & NA & $1.59 \mathrm{E}-02$ & $1.40 \mathrm{E}-02$ \\
\hline 4 & $<1.73 \mathrm{E}-02$ & $<1.74 \mathrm{E}-02$ & NA & $<1.76 \mathrm{E}-02$ & $1.22 \mathrm{E}-02$ & $1.26 \mathrm{E}-02$ \\
\hline 6 & NA & NA & $<1.75 \mathrm{E}-02$ & NA & NA & NA \\
\hline 12 & NA & NA & NA & NA & NA & NA \\
\hline 24 & NA & NA & $<1.75 \mathrm{E}-02$ & NA & NA & NA \\
\hline 168 & $<1.74 \mathrm{E}-02$ & $<1.73 \mathrm{E}-02$ & NA & $<1.71 \mathrm{E}-02$ & NA & NA \\
\hline 336 & $1.44 \mathrm{E}-02$ & $1.63 \mathrm{E}-02$ & NA & NA & NA & NA \\
\hline
\end{tabular}

Analytical uncertainty for samples above detection limit is $25 \%$.

"NA" indicates no analysis for the sample

\section{Uranium-238 Data}

\begin{tabular}{|c|c|c|c|c|c|c|}
\hline $\begin{array}{c}\text { Time } \\
(\mathrm{h})\end{array}$ & $\begin{array}{c}0.17 \mathrm{~g} / \mathrm{L} \\
\text { Fe } \\
\text { IS-MIO }\end{array}$ & $\begin{array}{c}0.17 \mathrm{~g} / \mathrm{L} \mathrm{Fe} \\
\text { IS-MIO } \\
\text { duplicate }\end{array}$ & MST & Control & $\begin{array}{c}0.25 \mathrm{~g} / \mathrm{L} \text { Fe } \\
\text { IS-MIO }\end{array}$ & $\begin{array}{c}0.25 \mathrm{~g} / \mathrm{L} \mathrm{Fe} \\
\text { IS-MIO } \\
\text { duplicate }\end{array}$ \\
\hline 0 & $2.00 \mathrm{E}+00$ & $1.83 \mathrm{E}+00$ & $1.97 \mathrm{E}+00$ & $1.92 \mathrm{E}+00$ & $1.95 \mathrm{E}+00$ & $1.93 \mathrm{E}+00$ \\
\hline $1 / 2$ & $1.86 \mathrm{E}+00$ & $2.08 \mathrm{E}+00$ & NA & NA & NA & NA \\
\hline 1 & $1.43 \mathrm{E}+00$ & $1.91 \mathrm{E}+00$ & NA & NA & $1.95 \mathrm{E}+00$ & $1.74 \mathrm{E}+00$ \\
\hline 2 & NA & NA & $1.50 \mathrm{E}+00$ & NA & $1.98 \mathrm{E}+00$ & $1.73 \mathrm{E}+00$ \\
\hline 4 & $2.03 \mathrm{E}+00$ & $1.73 \mathrm{E}+00$ & NA & $1.83 \mathrm{E}+00$ & $1.89 \mathrm{E}+00$ & $1.75 \mathrm{E}+00$ \\
\hline 6 & NA & NA & $1.34 \mathrm{E}+00$ & NA & NA & NA \\
\hline 12 & NA & NA & NA & NA & NA & NA \\
\hline 24 & NA & NA & $1.65 \mathrm{E}+00$ & NA & NA & NA \\
\hline 168 & $1.77 \mathrm{E}+00$ & $1.89 \mathrm{E}+00$ & NA & $1.74 \mathrm{E}+00$ & NA & NA \\
\hline 336 & $1.91 \mathrm{E}+00$ & $1.82 \mathrm{E}+00$ & NA & NA & NA & NA \\
\hline
\end{tabular}

Analytical uncertainty for samples above detection limit is $25 \%$.

"NA" indicates no analysis for the sample. 
This page was intentionally left blank 
This page was intentionally left blank 


\section{REFERENCES}

${ }^{1}$ D. T. Hobbs and D. D. Walker, "Plutonium and Uranium Adsorption on Mono-Na Titanate", WSRC-RP-92-93, August 13, 1992.

${ }^{2}$ D. T. Hobbs and S. D. Fleischman, "Fissile Solubility and Mono-Na Titanate Loading Tests", WSRC-RP-92-1273, February 12, 1993.

${ }^{3}$ D. T. Hobbs, M. G. Bronikowski, T. B. Edwards, and R. L. Pulmano, "Final Report of Phase III Testing of Mono Na Titanate Adsorption Kinetics", WSRC-TR-99-00134, Rev. 0, May 28, 1999.

${ }^{4}$ D. T. Hobbs, "Evaluation of Alternate Materials and Methods for Strontium and Alpha Removal from Savannah River Site High-Level Waste Solutions", WSRC-TR-2000-00229, Rev. 0, August, 2000.

${ }^{5}$ M. J. Barnes, D. T. Hobbs, M. C. Duff, and S. D. Fink, "Permanganate Reduction of Savannah River Site Actual Waste Samples for Strontium and Actinides Removal", WSRC-TR-200200048, Rev. 0, February 21, 2002.

${ }^{6}$ S. A. Slater, D. B. Chamberlain, S. B. Aase, B. D. Babcock, C. Conner, J. Sedlet, and G. F. Vandegrift, "Optimization of Magnetite Carrier Precipitation Process for Plutonium Waste Reduction”, Separation Science and Technology, 32(1-4), 127-147, 1997.

${ }^{7}$ M. S. Grigoriev, A. M. Fedoseev, A. V. Gelis, N. A. Budantseva, V. P. Shilov, V. P. Perminov, M. V. Nikonov and N. N. Krot, "Study of the Interaction of Pu(IV) and Np(IV,V, VI) with Fe Hydroxides to Predict the Behavior of Actinides in Environmental Media", Radiochimica Acta, 89, 95-100, 2001.

${ }^{8}$ H.A. Arafat, A.V. Gelis, and G.F. Vandegrift, "Operational Envelop for Studies Using Magnetite to Remove Strontium and Actinides from SRS Tank Waste,"

ANL Letter Report ANL/Magnetite-2002/01-Rev 1, May 15, 2002.

${ }^{9}$ H.A. Arafat, S.B. Aase, A.J. Bakel, D.L. Bowers, A.V. Gelis, M.C. Regalbuto, J. Sedlet, and G.F. Vandegrift, "Parametric Studies on the Use of In-Situ Formed Magnetite for the Removal of Sr and Actinides from Tank Waste at the Savannah River Site," ANL Letter Report ANL/Magnetite-2002/02, August 4, 2002.

${ }^{10}$ M. J. Barnes, T. B. Edwards, D. T. Hobbs, K. M. Marshall, "Strontium and Actinide Removal Testing with Monosodium Titanate and other Sorbents", WSRC-TR-2001-00436, October 29, 2001.

${ }^{11}$ N. R. Mann, R. S. Herbst, T. G. Garn, M. R. Poirier, and S. D. Fink, “Alternative Ultrafiltration Membrane Testing for the SRS Baseline Process", INEEL/EXT-04-01933, June, 2004. 
${ }^{12}$ M. R. Poirier, "FY2000 FRED Test Report,”WSRC-TR-2001-00035, Rev. 0, January 11, 2001 and included report "Final Report on the Crossflow Filter Optimization with 5.6 M Sodium Salt Solution" (V. Van Brunt, C. Stork, T. Deal, and R. Haggard, USC-FRED-PSP-RPT-09-0-015, December 20, 2000).

${ }^{13}$ V. Van Brunt, R. Haggard, T. Deal, C. Stork, M. R. Poirier, and S. D. Fink, "Cross-Flow Filtration of Simulated High-Level Waste Sludge (Tank 8F)", WSRC-TR-2001-00195, April 20, 2001.

${ }^{14}$ H. H. Saito, M. R. Poirier, S. W. Rosencrance, and J. L. Siler, "Improving Filtration Rates of Mono-Sodium Titanate (MST)-Treated Sludge Slurry with Chemical Additives", WSRC-TR-9900343, September 15, 1999.

${ }^{15}$ M. R. Poirier, T. M. Jones, S. D. Fink, R. Haggard, and V. Van Brunt, "Evaluation of Mott Filter Performance: Solids Removal Efficiency”, WSRC-TR-2002-00256, May 30, 2002.

${ }^{16}$ M. R. Poirier, J. L. Siler, S. D. Fink, R. Haggard, T. Deal, C. Stork, and V. Van Brunt, "PilotScale Testing of a 0.1 Micron Filter with SRS Simulated High Level Waste", WSRC-TR-200300469, October 8, 2003.

${ }^{17}$ M. R. Poirier, J. L. Siler, and Samuel D. Fink, "Filtration of Actual Savannah River Waste Treated with Permanganate or Monosodium Titanate", WSRC-TR-2002-00134, March 14, 2002.

${ }^{18}$ M. J. Barnes, F. F. Fondeur, D. T. Hobbs, S. D. Fink, "Monosodium Titanate Multi-Strike Testing", WSRC-TR-2004-00145, April 29, 2004.

${ }^{19}$ C. Pereira, S. B. Aase, A. V. Gelis, M. C. Regalbuto, G. F. Vandegrift, K. Martin, S. Serkiz, S.G. Subosits, and S.D Fink, "Preliminary Flowsheet for the IS-MIO Process for Sr and Actinides Removal from SRS Salt Waste”, ANL/CMT/IS-MIO-2004/01, March 4, 2004.

${ }^{20}$ Notebook WSRC-NB-2004-00097. 